\title{
Clonagem: criador e criaturas rumo a mundos possíveis
}

\section{Cloning: creator and creatures headed towards possible worlds}

$\mathrm{E}$ m março de 1997, jornais e revistas do mundo inteiro deram com destaque a notícia do feito realizado pela equipe do embriologista Ian Wilmut no Roslin Institute, próximo a Edimburgo, Escócia. A imagem da ovelha Dolly, replicada milhares de vezes mundo afora, inflamou a imaginação de leigos e especialistas e suscitou indagações cruciais que continuam a mobilizar os mais diferentes campos disciplinares. Não era o primeiro clone que se engendrava, mas Wilmut, além de criar um mamífero perfeitamente saudável a partir de uma única célula adulta, provou que esta podia reverter ao estágio embrionário para originar um novo ser. "Desde que Deus apanhou uma costela de Adão para confeccionar-lhe uma companheira, nada de tão fantástico tinha acontecido", exclamou um dos autores da reportagem especial publicada pela revista Time (10.3.1997, pp. 34-43). Logo se difundiram, também, as comparações com o monstro fabricado, no plano ficcional, pelo dr. Frankenstein, o médico alucinado que Mary Shelley inventou no começo do século. As duas comparações - homem demiurgo de maravilhas ou de monstros - perpassam os inumeráveis debates que Dolly desencadeou. Questões éticas fundamentais estão na ordem do dia, junto com a consciência de que a humanidade está à beira de passos decisivos. Não se sabe se para o bem ou para ou mal dela própria e dos seres - existentes, modificados ou a criar - que compartem uma natureza cada vez mais distorcida, 'humanizada', perecível. A clonagem dos macaquinhos Neti e Ditto feita logo a seguir, o confronto final entre o enxadrista russo Garry Kasparov e a máquina Deep Blue, da IBM, a criação da ovelha Polly e o primeiro cultivo de células humanas básicas em laboratório, a partir de células de fetos abortados — notícias publicadas em julho, quando fechávamos esta edição - só fizeram reforçar a impressão de que o novo milênio reserva-nos cenários que deixam para trás as mais arrojadas science fictions inventadas pelo homem. Em outras palavras, as ciências da natureza estão se mostrando capazes de produzir realidades virtuais que ultrapassam os prodígios concebidos ou antevistos pelos ficcionistas.

$O$ evento Dolly teve outras significações profundas: generalizou a consciência de que precisamos rever categorias basilares do pensamento para podermos responder às exigências que estas realidades nos impõem e para nos colocarmos à altura de uma responsabilidade que os filósofos deste milênio e do anterior já assinalavam: o homem é, a um só tempo, sujeito e objeto de uma história irreversivelmente universal. 
A revista História, Ciências, Saúde - Manguinhos repercute as ondas de choque propagadas por aquele evento reproduzindo dois debates ocorridos recentemente no Rio de Janeiro. Um foi promovido pelo Museu de Arte Moderna (MAM), no âmbito da mostra 'Clones', em 9 de maio de 1997. Coordenado por Susana Schild, reuniu Luiz Alberto de Oliveira, pesquisador do Centro Brasileiro de Pesquisas Físicas (CBPF), Paulo Vaz, professor da Escola de Comunicação da Universidade Federal do Rio de Janeiro (UFRJ), e Luis David Castiel, do Departamento de Epidemiologia da Escola Nacional de Saúde Pública (Ensp). O outro foi organizado pela Fundação Oswaldo Cruz (Fiocruz), em 7 de abril, como parte do workshop sobre 'Doenças Emergentes e Reemergentes no Contexto da Biossegurança'. Da mesa coordenada por Leila Oda, do Departamento de Estudos em Ciência e Tecnologia do CICT/Fiocruz, participaram o jurista Paulo Affonso Leme Machado, a historiadora Marli de Albuquerque (Casa de Oswaldo Cruz/Fiocruz), Win Degrave, pesquisador em biologia molecular (Instituto Oswaldo Cruz/Fiocruz), o imunologista Orlando Ferreira Júnior, do Hospital Albert Einstein, e um especialista em bioética, Marcos Segre, da Faculdade de Medicina da Universidade de São Paulo (USP). Ambos os debates contaram com platéias participantes, destacando-se, na primeira, o psicanalista Waldemar Zusman, e, na segunda, Fernanda Carneiro, Fermin Rolland Schramm e a senadora Marina Silva (PT-AC).

Os leitores hão de perceber as inclinações diferenciadas de cada um destes fóruns e certamente lucrarão com isso. O do MAM arregimentou um público interessado não só no frisson causado por Dolly, como na releitura da ficção cinematográfica à luz da clonagem, que permite alinhavar clássicos como Frankenstein (1933), Vampiros de almas (1956), Blade Runner: o caçador de andróides (1982) etc. As discussões tiveram um viés mais filosófico nesse fórum, em que afloraram com mais força as analogias com monstros, o espectro de Frankenstein. O workshop da Fiocruz reuniu atores envolvidos mais diretamente com a produção científica e o debate teve, então, um cunho mais prático, talvez pragmático, com certeza mais otimista. As diferenças transparecem até no estilo dos dois textos: o primeiro derramando imagens, metáforas; o segundo, seco, sóbrio...

Tenham bom proveito.

Anna Beatriz de Sá Almeida Jaime Benchimol 
"Ao contrário de épocas passadas, em que tradições ético-populares ou religiosas nos forneciam imagens para darmos sentido ao mundo, hoje, esse lugar é assumido pelo discurso científico."

\section{Susana Schild}

Se nós escolhemos o filme Frankenstein para abrir o debate é porque o romance, escrito em 1918, e o filme, realizado em 1933, criaram uma nova abordagem da questão dos monstros. Nesse caso, o monstro foi criado pela ciência. Até Mary Shelley escrever Frankenstein, eles em geral vinham da Idade Média, das trevas. Tinham origens nebulosas, acientificas, ancestrais. Com o Frankenstein, não. É criado pela ciência, por um médico, num processo que envolve os avanços científicos do início do século, a eletricidade, novos conhecimentos sobre o corpo. Enfim, hoje talvez isso pareça medieval, já que os acontecimentos ligados à clonagem estão associados a partículas de corpos. Conversar sobre clonagem é um pretexto para discutirmos questões pertinentes à ética, à bioética e à relação com o outro.

Quando pensamos no debate, o assunto estava quente. Naquelas semanas só se falava nisso. Mas nós temos um timing, e agora que conseguimos programar o evento, não se fala mais da ovelha Dolly. Mas que a gente não relaxe: eles estão armando outras nos laboratórios.

\section{Luiz Alberto de Oliveira}

Pretendo apresentar-lhes certas noções que nos permitam compreender com mais precisão o que está acontecendo neste momento. No futuro, das tantas coisas que nossa época faz, talvez ela venha a ser lembrada pelo fato de se ter constituído e se ter tornado predominante uma nova fonte de imagens para dar sentido ao mundo, um novo discurso, o discurso científico. Ao contrário de épocas passadas, em que tradições ético-populares ou religiosas nos forneciam, imagens para darmos sentido ao mundo, hoje, esse lugar é assumido pelo discurso científico. Ele é a fonte de imagens do mundo. Isso acontece porque a ciência aplicada à tecnologia tornou-se a maior varinha de condão que o homem já possuiu para compreender e transformar a realidade.

Foi esse poder que assegurou ao discurso e à idéia de ciência o lugar predominante na formação de sentido comum. Acredito que três noções sejam suficientes para se compreender qual o novo lugar que a vida, os seres vivos, os processos vitais ocupam em nossa época. Podia enumerar cinqüenta, mas três serão suficientes para alimentar o debate.

Em primeiro lugar vem a desaparição do intervalo, da distância entre o inanimado e o animal, entre o vivo e o não-vivo. Seria, vamos dizer assim, o término do vitalismo, pois até certo tempo atrás se acreditava que havia uma diferença de essência, de natureza, entre o ser vivo e o não-vivo. Como se o primeiro tivesse algo a mais, uma anima, alma, substância, força vital que o distinguia dos demais seres inanimados. Tal distinção teve variadas inflexões ao longo da história. Mas num certo momento, na Idade Média, por exemplo, quando a concepção de mundo era a de um grande organismo em que tudo tinha seu lugar, cumprindo cada lugar a função de garantir a harmonia cósmica global, então havia certa predominância de imagens vitalistas sobre as imagens da natureza bruta. Mais recentemente, em especial no século passado - e o filme é muito revelador a esse respeito - , uma nova concepção toma conta das descrições do mundo natural: o mecanicismo. Este caracteriza-se por ser uma grande metáfora, segundo a qual o universo é um análogo de uma grande máquina. E tudo que existe então pode ser pensado em termos de engrenagens que se concatenam e fios que conduzem 
"Hoje o passo mais significativo para o novo lugar da vida no campo do pensamento é o desaparecimento da fronteira entre o vivo e o nãovivo... $\mathrm{Na}$ verdade, tudo o que existe aqui é poeira de estrelas." energias e forças, atuando de tal maneira que a própria vida passou a ser concebida em termos mecânicos. Até mesmo o pensamento passou a ser pensado em termos mecânicos. E essa é uma herança que carregamos até o presente. Mas hoje o passo mais significativo para o novo lugar da vida no campo do pensamento é o desaparecimento da fronteira entre o vivo e o não-vivo. Os seres vivos não se distinguem substancialmente, ou seja, por sua constituição, por aquilo de que são feitos, dos seres não-vivos. Não há nos primeiros nenhuma matéria a mais, nenhuma matéria distinta daquela que constitui os não-vivos. Na verdade, tudo o que existe aqui é poeira de estrelas. Todos os nossos átomos foram engendrados, cozinhados numa estrela colossal que explodiu e lançou no espaço interestelar este material que se condensou numa segunda geração de estrelas. Alguns restinhos formaram estes tais de planetas em que habitamos. Então toda a matéria, tudo aquilo que existe - esta é uma descoberta realmente estarrecedora - é feito da mesma coisa. Eis o primeiro fato. O vitalismo terminou. Somos todos poeira de estrelas.

A segunda noção é um pouco mais complexa. Refiro-me à desaparição, novamente, da distância, de uma separação de natureza entre instinto e matéria. Em outras palavras, desaparecimento da separação clássica entre sujeito e pensamento, entre objeto e pensamento. De maneira que, agora, não podemos considerar o mundo como realidade prévia ao nosso próprio ato de conhecer. As formas do mundo não são prêt-à-porter. É necessário um diálogo com o pensamento para que possam ser apreendidas, possam receber sentido. Mas não quero me alongar muito neste terreno extremamente perigoso que estou pisando. Vou apontar, simplesmente, a substituição da noção de indivíduo - aquele que tem um molde prévio que cai sobre a matéria e é forma - pela noção de individuação. Aqui, a forma não vem de fora, é produzida endogenamente, através de uma operação de individuação que implica etapas, sucessões, partes que se concatenam segundo um ritmo, um programa bem definido. Portanto, a matéria da vida deixa de ser a substância, a massa, e passa a ser temporalidade. Vida é um modo diferente de o mundo se ordenar, temporalizar. É uma invenção de novas tramas de tempo.

A terceira noção corresponde à mais significativa descoberta científica que o homem já fez sobre o mundo natural. É a descoberta de que todos os astros, todos os seres, todas as matérias, esta entidlade que chamamos de universo, cosmo, encontra-se num estado dinâmico de expansão. Ou seja, a totalidade está em transformação. É inacabada. Logo, não foi dada ainda a última palavra sobre o que é a natureza.

Podemos, então, combinar estas três noções — o fim do vitalismo, o fim do indivíduo, substituído pela noção de linha de tempo, e a noção de totalidade inacabada - para confeccionar um novo cenário para a vida. Ela é alguma coisa que não vem de fora da matéria, que brota endogenamente. A matéria tem potência de engendrar-se em vida, e a vida tem o princípio da expansão, o princípio da invenção de novos modos de ordenação. Isso corresponde ao atributo da totalidade. No ridículo asteróide, que gira em torno de uma estrela comum à beira de uma galáxia com cem bilhões de outras estrelas, galáxia que é uma entre cem bilhões de outras galáxias, neste minúsculo fragmento de quase nada nós já podemos distinguir algo que é um sintoma da totalidade. Estarmos vivos é estarmos inventando novas formas de ordenação que eram 
apenas potência. Nesse novo contexto, radica uma concepção de vida que vou procurar explicar da seguinte forma: vamos imaginar cubinhos de letras, cada um com uma letra. Podemos dizer que são os constituintes elementares da matéria, os átomos, por assim dizer. Esses cubinhos se reúnem formando fonemas, os fonemas se reúnem e formam palavras, estas se reúnem para formar frases, as frases formam textos, discursos, catálogos, bibliotecas. Podemos pensar a vida como sendo uma curiosa classe de frases e palavras que têm o poder de se reescrever. Ou seja, o poder da vida é se repetir, se replicar, e esse poder a torna, num certo sentido, aquilo que Borges dizia que não podia existir: o autor de si próprio. Então, é como se a vida se escrevesse, reunisse as palavras que estão aptas a programar equipamentos que vão reproduzir palavras... Esse é o jogo da vida. O jogo tem dois elementos principais. Um é a replicação mais exata possível dos termos básicos do discurso que são os seres vivos, portanto uma invariância, permanência, um certo tipo de tempo. Por outro lado, um tempo de modificação, de transformação, que é o encontro da vida com o acaso, quando uma letra troca de lugar e daí sai alguma coisa que adquire larga escala na nova repetição, algo que vai ser filtrado, selecionado pelo jogo da vida com ela própria, dos seres vivos consigo mesmos e com seu ambiente. Pensando dessa forma tão esquemática, talvez possamos começar a compreender o alcance do fato de termos sidos capazes, há cerca de quarenta anos, de decifrar o código da vida, esta maneira de produzir textos e palavras que é característica da vida. Para além do mecanismo que há bilhões de anos tem assegurado a repetição dela, tal conhecimento nos autorizou, pela primeira vez, a programar o que vai ser escrito no livro da vida. Agora temos o poder de juntar as letrinhas que vão corresponder a novos seres vivos. Se possuímos ou não a sabedoria para fazer isso, é tema difícil que entrego a meus colegas. Limito-me a chamar a atenção para a enormidade deste poder de engendrar novas formas no mundo, novidades no mundo. É poder demais! Até um tempo atrás, o homem podia produzir certa modificação em determinada espécie. Ficava aguardando o tempo da reprodução do animal, estimulando, geração após geração, aquelas características que lhe interessavam mais. Era um processo em que a atividade humana pegava carona na evolução darwiniana natural. Agora não. Temos o poder de programar o que vai ser produzido, de acrescentar novos seres ao mundo dos existentes. Juntos aos biontes que somos nós, seres biológicos criados pela evolução natural, vão começar a surgir os 'bióides', seres vivos produzidos a partir de outra programação, que é da inteligência - ou falta de inteligência. O primeiro 'bióide' notável é a Dolly. Embora não seja o primeiro historicamente, é o que se popularizou. E um segundo tipo de vida vai começar a aparecer, não vai demorar muito. Sem fazer futurologia excessiva, mais uns vinte e poucos anos, vamos nos reunir aqui para ver filmes sobre os borgies, que são a mescla de equipamentos produzidos por seres vivos com equipamentos 'mecânicos', por exemplo, vírus artificiais, proteínas feitas de matéria plástica etc.

Então estamos vivendo um momento renascentista, investindo na eliminação da fronteira entre o vivo e o não-vivo, entre o natural e o artificial. Acho da maior importância que tomemos consciência de que estamos vivendo uma vertiginosa transformação nos próprios fundamentos com os quais estamos acostumados a viver, a pensar a vida, a pensar o mundo, as relações que entretecemos. É absolutamente indispensável que debatamos 
“O que está em jogo, aqui, é o que sempre esteve: a liberdade." e nos informemos sobre este poder sobre a vida, bem como sobre as direções — pró ou contra, não importa — que, de algum modo, possamos imprimir a seu uso. Porque o que está em jogo, aqui, é o que sempre esteve: a liberdade.

\section{Susana Schild}

Agora vamos ouvir o médico que vai representar a ciência, não é?...

\section{Luis David Castiel}

Assim eu não vou falar. Diante dessa responsabilidade, vou tirar o corpo fora. Porque, fortuitamente, sou médico epidemiologista, não sou biólogo molecular. Talvez fosse esta a autoridade que devesse estar aqui falando.

Não sou embriologista, não sou geneticista, nem faço criação de ovelhas. Aí vocês vão pensar, o que este cara está fazendo aqui? Na verdade, estou ocupando o lugar de médico charlatão, ou melhor, charlador. Charlar, no Rio Grande do Sul e na Argentina, significa falar, talvez, despropositadamente, e eu vou fazer um pouco isso. Mas meu foco é a relação desta tal de biomedicina ou biotecnociência com as dimensões simbólicas, culturais que estamos tentando preservar em certa medida.

Também vou falar como alguém que está perplexo, que está tentando dar algum sentido a estas novidades avassaladoras que a cada semana os jornais despejam sobre nós. Aliás, gostaria de perguntar quanto está o score do jogo Garry Kasparov contra Deep Blue, porque atualmente já não se trata mais de saber o resultado do jogo de futebol, mas quem está ganhando, os humanos ou as máquinas. E, também, quem é quem. Em geral, a torcida pergunta: "Quanto está o jogo? Nós estamos ganhando?" Mas nós quem, cara pálida? Por acaso não tem o cientista da IBM desse lado também? Bom, eu acho que há uma questão específica no caso da Dolly, que é a difusão da notícia. Há um bom tempo está surgindo um jornalismo científico que não existia, e agora houve uma concomitância planetária em que todos os semanários estamparam a ovelha escocesa em suas capas. No decurso deste tempo - dois meses - já aconteceram outras coisas. A Dolly já virou chiste de televisão, de festas... Sinto que há um risco de a gente perder a compostura séria, científica, e embarcar numa certa palhaçada. Por isso pensei muito num título para esta charla. Pensei 'De clones e clowns', repetindo um jogo que revistas americanas e inglesas de divulgação científica fizeram. Mas é uma injustiça com todos nós, porque, mesmo saindo da crista do noticiário, o tema clones é, a meu ver, difícil de ser digerido. Como podemos discutir uma perspectiva razoável sem nos assustarmos? É para quando este clone humano? Vinte anos, como sugeriu o Luiz Alberto? Antes da Copa de 98? Em 2001?

Já que sou o representante da ciência, vou tranqüilizá-los: não tenho a mínima idéia. Esta história ocorre desde pelo menos a década de 1950, quando se fez a clonagem de batráquios. Mas batráquios ficam longe, não é?, se a gente pensar em termos de escala zoológica. Estava sendo esperada, de certa forma, a clonagem em mamíferos. Revisei um texto de 1991 que dizia que era questão de tempo. Bem, aconteceu e agora algo tem de ser feito. Aí pensei num outro título: 'Crônica - ou clônica - de um nascimento anunciado', mas é muito fraco. Uma das particularidades do caso Dolly, especialmente perigosa para a masculinidade, é que não houve a participação de nenhum gameta masculino. Não teve macho na história. É claro que não 


“O animal
clonado
enquadra-se
numa simbologia
cristã - o
cordeiro de Deus.
Curiosamente,
este que está nos
jornais parece se
identificar mais
com o cordeiro
do diabo..."

estou colocando em dúvida a sexualidade do professor que realizou a proeza. Os objetos foram, na verdade, três senhoras - três ovelhas (tenho que ser politicamente correto aqui). Uma foi a doadora do núcleo de célula mamária. Esta mesma ovelha, de focinho branco, forneceu a célula de ovário, que teve o núcleo retirado e que recebeu o núcleo mamário. Deu-se uma descarga elétrica e, frankensteinamente, o DNA entrou em ação. Este ovo foi colocado em uma barriga de aluguel, de outra raça - uma ovelha de focinho preto - a segunda, para não perder a conta. A terceira é nossa gloriosa Dolly.

Já que estamos no cinema, não podemos deixar de aludir aos clones naturais, os gêmeos. Temos vários: Os irmãos Corsos, O príncipe e o mendigo, aqueles gêmeos mais recentes da mórbida semelhança. Em geral a questão que aparece nestes filmes é a troca de lugares, de identidades ou a surpresa causada por um duplo idêntico, especular.

Bem, acredito que não há mais dúvida de que, cedo ou tarde, vão se clonar humanos e, como diz uma revista de divulgação, a New Scientist (Editorial, vol. 153, n² 2.072, 1997), este será um ponto de não-retorno. Agora, a pergunta que faço é: Apocalypse now? A palavra apocalipse é interessante, porque significa cataclisma, essa idéia de desastre que gera o caos, mas também tem o sentido de revelação, descoberta, desvelamento, o que condiz perfeitamente com as possibilidades abertas por esta era biotecnocientífica. Pois, além do lado preocupante, existe um projeto de aperfeiçoamento humano, de uma reprogramação do próprio estatuto da espécie humana, como sugeriu o Luiz Alberto. Ao ocorrer isso, a gente lida com dimensões que eram vistas como alheias a nossa vontade terrena. Até há pouco tempo, os responsáveis por estes afazeres eram entidades divinas. Agora não são mais. Apocalipse também significa um gênero literário bíblico no qual eventos e predições do passado são revistos à luz de fatos do presente e da aproximação final. É um mito que se repete a cada final dos tempos. O próximo, aliás, está programado para acontecer no ano 2000. É bom preparar as nossas agendas, inclusive para o problema seriíssimo de computador. Não acredito que se possa deter a clonagem do homem, apesar do furor legislante dos governos e da grita dos religiosos contra esta heresia. Tem gente, inclusive, que acha que isso já aconteceu, em algum lugar por aí, clandestinamente. Talvez os agentes do Arquivo X venham a descobrir! Tomando uma certa liberdade, acho que algum megamilionário excêntrico pode financiar o projeto de sua própria replicação. Com mais liberdade ainda, pergunto a vocês se não acham que o Michael Jackson não seria o candidato natural, já que ele reservou uma câmara hiperbárica para se conservar. Pergunto até, assim bem ao nível de papo de botequim, como terá ele fecundado a enfermeira Debbie? In vivo ou in vitro? Se já houvesse a possibilidade de replicação, ele nem precisaria fazer esse cruzamento. Há um aspecto irônico que foi assinalado por José Miguel Wisnik (6.5.1997), numa palestra sobre clonagem. Ele chamou a atenção para algo que talvez as pessoas já tenham percebido. $O$ animal clonado, a ovelha, enquadra-se numa simbologia cristã — o cordeiro de Deus. Curiosamente, este que está nos jornais parece se identificar mais com o cordeiro do diabo, porque ele contraria as leis naturais abençoadas por Deus. A Dolly não é bonita por natureza, é por artifício humano. Para encerrar a questão do título - eu ainda estou nos títulos - sugiro, talvez forçando um pouco a barra, 'Do gênesis ao clonisis', porque estamos vivendo um momento que pode ser chamado de 'clônisis'. E um subtítulo mais 
abusivo ainda: 'Deus e o Diabo na terra do sol e abaixo dela'. Isso vou tentar explicar, depois, se vocês me suportarem.

Há uma coletânea de textos editada na França em 1985, um livro sem organizador que foi traduzido e publicado recentemente no Brasil com o título A ciência e o imaginário. Em um dos textos, Jean Marigny (1996), autor que eu não conhecia, faz uma classificação dos tipos de literatura fantástica e de ficção científica em que o incrível, o inexplicável e o extraordinário acontecem. Um clássico da coexistência da ciência com o irracional é $O$ médico e o monstro, que já teve várias versões cinematográficas, desde a mais trágica, com Spencer Tracy, em bela interpretação, aliás, até as comédias, versões eróticas, com situações até de transexualidade. Outra vertente é o fracasso da ciência diante do irracional. O caso emblemático é o Drácula de Bram Stocker. Num dado momento, o mocinho mais velho da história fala para o médico, que está tratando da mocinha que não consegue explicar o que está acontecendo pela ciência e que precisa se ancorar na superstição. Outro modelo é o irracional racionalizado pela ciência. O exemplo clássico é Frankenstein. Os invasores de corpos também constituem um veio literário, e eu resolvi incluir mais um, apesar de não figurar nesta tipologia, que é a ciência como instrumento que se pretende antecipatório. Caso de 2001, uma odisséia no espaço, um clássico também, o recente Jurassic Park, com sua seqüela de clones, e outro clássico de clonagem que não vi mencionado, Meninos do Brasil, no qual réplicas de Hitler são dispersas por várias famílias da América do Sul. Este traz uma discussão sobre o inato e o adquirido, bem ao alcance do senso comum: espera-se que a educação dos pais adotivos seja tão diferente da educação que Hitler recebeu na Áustria, que não dê no que deu.

Tem, ainda, a versão de um livro que ficou famoso, chamado Crash! bela onomatopéia, aliás, para este momento - que virou um filme lançado este ano. Sobre o tema, L. G. Santos publicou longo artigo na Folba de S. Paulo (16.3.1997). Na introdução do livro, o autor J. P. Ballard (1988) discorre sobre os efeitos das tecnociências nas relações sociais da atualidade:

o principal fato do século XX é o conceito de possibilidade ilimitada. Este predicado da ciência e da tecnologia enfatiza a noção de uma moratória sobre o passado, a irrelevância e mesmo a morte do passado, e as ilimitadas alternativas disponíveis para o presente. O futuro também está deixando de existir, devorado pelo presente, que é todo voracidade. Anexamos o futuro ao nosso próprio presente como mais uma simples alternativa entre as múltiplas que se abrem para nós. As opções multiplicam-se ao nosso redor. Vivemos em um mundo quase infantil, no qual qualquer demanda, qualquer possibilidade, seja por estilo de vida, viagem, papéis sexuais, identidade, pode ser instantaneamente satisfeita.

Aí eu acrescento uma ressalva: desde que se tenha poder aquisitivo para isso, é claro! Ballard vai adiante. Ele considera que houve uma inversão dos papéis atribuídos à realidade e à ficção:

Vivemos num mundo governado por ficções de toda espécie: do merchandising de massa à publicidade, à política conduzida como um ramo da propaganda, à tradução instantânea da ciência e da tecnologia 
em imagens populares, à crescente mistura e interpenetração de identidades no reino dos bens de consumo, à apropriação pela televisão de qualquer resposta imaginativa livre ou original em experiência. Enfim, nossa vida é uma grande novela ou ficção.

Corte para outra cena. Uma mansão luxuosa, com quadra de tênis, piscina, campo de golfe. Parece uma dessas propagandas, não é? Dezoito homens e 21 mulheres são encontrados mortos ali num ritual de suicídio coletivo. Como todos sabem, pertenciam a uma seita apocalíptica — olha a gente de volta ao apocalipse - e, para fugir do inferno, fizeram uma mistura fatal envolvendo sexo, drogas e rock and roll com informática. Falta de sexo, na verdade, porque muitos haviam sido castrados. Tinham uma empresa que desenhava páginas para a Internet, e em vídeo - acho que vocês viram isso no noticiário - o líder da seita anunciou a decisão de se desfazerem do invólucro corporal para alcançarem o disco voador escondido na cauda do cometa Halle Bopp. Tinham em mira a ressurreição. Vou dar um palpite abusivo sobre esse fato que aconteceu um mês depois da Dolly: acho que estão vinculados por oposições e equivalências bem interessantes, pois ambos os casos têm a ver com técnicas de indução artificial, a Dolly com um nascimento extremamente sofisticado, o outro caso com uma técnica artificial de morrer, já que eles escolheram se matar com barbitúricos, drogas, fármacos. Ambos envolvem o uso de tecnologias avançadas, manipulação do DNA, Internet... Põem em jogo, também, o conflito entre o racionalismo de uma ciência exacerbada e o irracionalismo de crenças místicas exacerbadas, assim como aspectos simbólicos referidos a enigmas humanos primordiais: o de origem e o de destino. Há, ainda, uma questão que considero essencial, a fragilidade atual da constituição e manutenção da identidade. A identidade do humano, em nossa cultura ocidental, tem se afirmado na negação da dita natureza, afirmando diferenças. Ou seja, o homem moderno fez um pacto diabólico, faustiano, na tentativa de se transformar em outra coisa, modificar-se com a cultura que engendra: agora, é inteiramente por meio dela e não mais por si que será engendrado. Chegamos a um ponto em que um dos elementos de nossa gênese, que é a reprodução, pode ser alterado de forma radical.

Como todo mundo sabe, a procriação humana se dá mediante dois seres que se unem amorosamente - em tese, pelo menos. Conjugação de dois seres de gêneros diferentes - daí cônjuges, da mesma origem etimológica - para a geração de um terceiro. Primado de Eros, que, na teogonia de Isidro, era uma divindade agrícola responsável pela fertilidade da terra, que fazia os corpos se moverem uns em direção aos outros, propiciando a união. Eros era o dia e o éter, o espaço celeste. Só que há outra forma de reprodução, como insinuou o Luiz Alberto, a reprodução assexuada, mediante a divisão, em que um gera dois, própria de seres proliferantes debaixo da terra, do mundo do caos, que produz a noite, e o érebo, uma região tenebrosa, o inferno. Pois bem, com a clonagem - e agora estou sendo intencionalmente dramático - parece que o caos começa a assumir a reprodução não-sexual, sem fusão, dos humanos, pondo em confronto bem e mal, simbólico/diabólico. Diabólico tem uma etimologia curiosíssima. É aquele que é lançado para cortar, atravessar, separar, diferentemente do simbólico, que é aquilo que é lançado para unir, ordenar. Ou seja, está em curso o desancoramento do simbólico e das formas de pensar a procriação, e o mundo desencanta-se 
: $\mathrm{yb}:=$

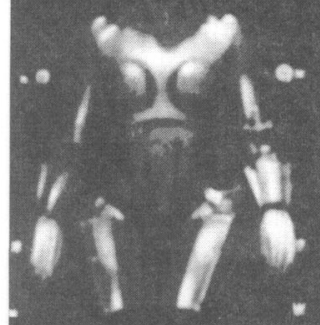

Cena de Metrópolis (1926), filme de Fritz Lang. (Franz Rottensteiner, La science fiction illustrée: une histoire de la S. F. Paris, Seuil, 1975 , pp. 80-1.)
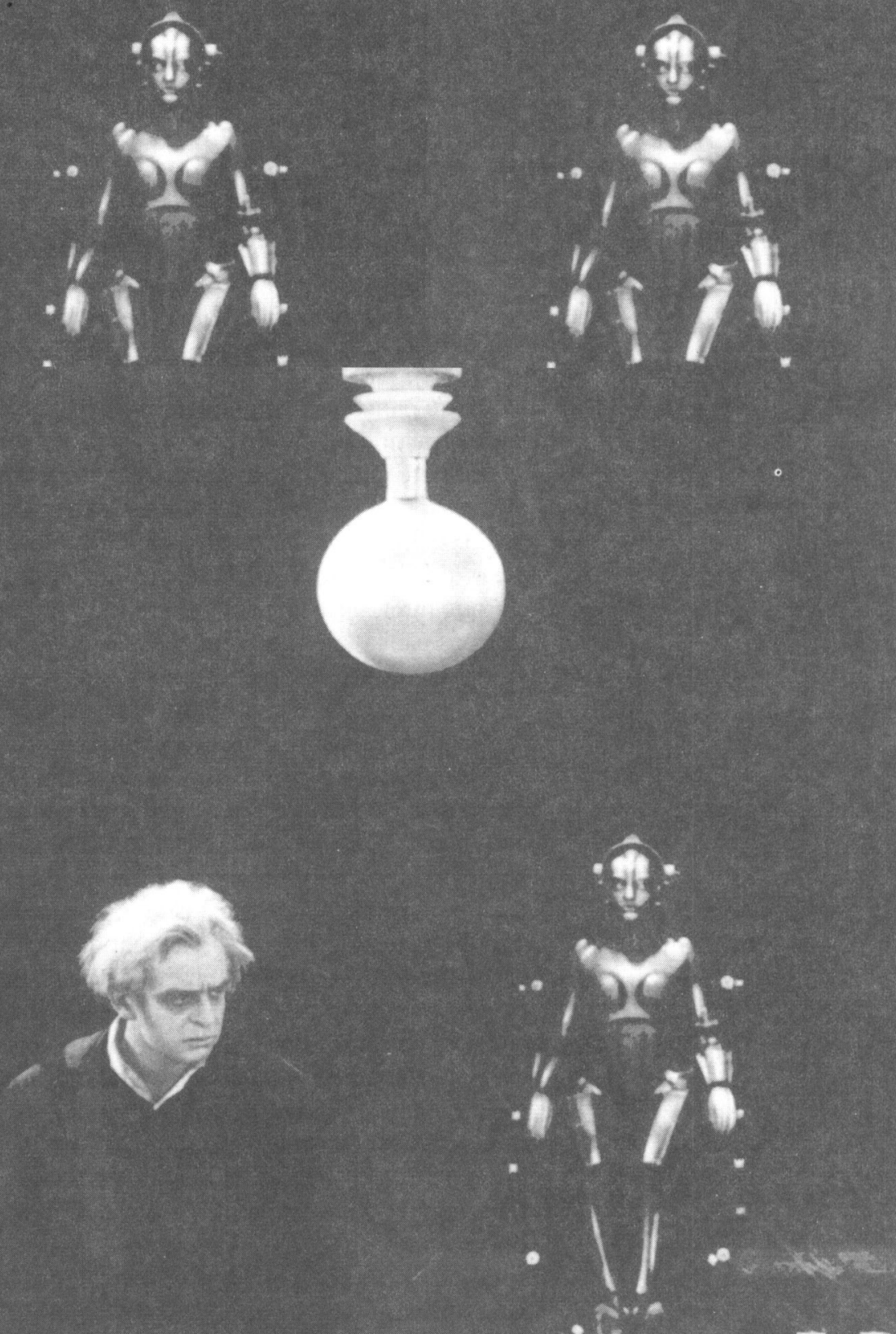

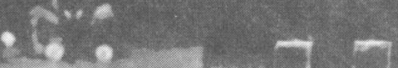
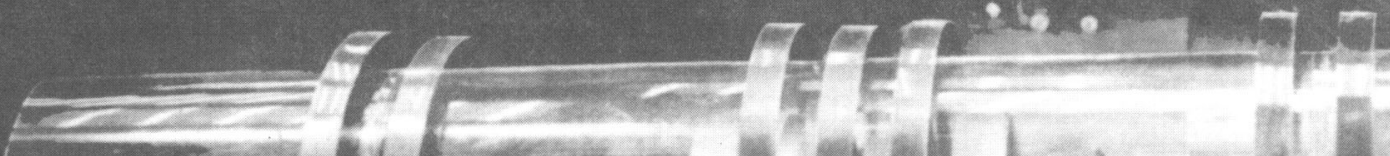

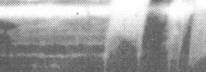

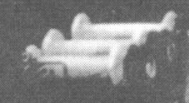

H. II:

MIIIJ)

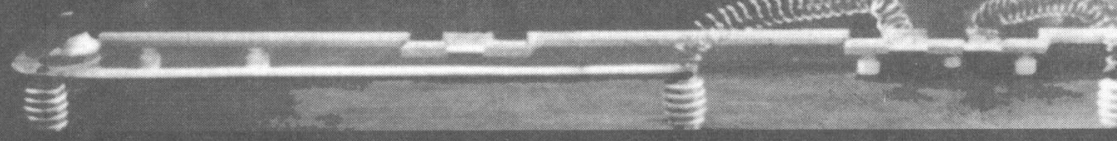

$: 95=$

(4)

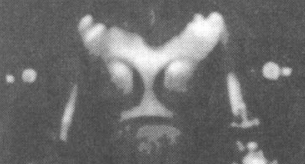

If $x+x^{2}$ 
com a fragilização das crenças, das matrizes que davam sustentação às nossas identidades e sentimentos.

J. F. Lyotard (1996, pp. 207-8) diz: "A estética é o modo de uma civilização abandonada por seus ideais cultivar o prazer de representá-los (um prazer que se perverte, deprava, pois enfatiza), a encenação, a espetacularização, a mediatização, a simulação, a hegemonia dos artefatos, a mimese generalizada, o hedonismo, o narcisismo, o auto-referencialismo, a autoficção, a autoconstrução e outras." Ainda bem que tem outras, senão... Nossa autoconstrução está se consumando num mal diabólico, no sentido que tentei apresentar. Está se tornando replicante, com a construção artificial do mesmo que não é o mesmo. Isso tem um aspecto favorável. Afinal de contas, a gente pode ter o controle de doenças genéticas, produzir animais transgênicos, tecidos destinados à pesquisa, melhorias biotecnológicas na agropecuária. Mas há um curto-circuito chocante, uma agudização ainda maior de nossas crises. Então, face a esta mistura - ficção superada pela realidade, autoprodução, narcisismo etc. —, resolvi propor uma estetização enlouquecida, para encerrar essa conversa que já foi enlouquecida. É a sinopse de um roteiro para continuação de dois filmes: a série Profecia, que vocês conhecem, aquela que tem Profecia 1, 2, 3, 4, o retorno, a volta, o filho, junto com $O$ bebê de Rosemary, filme que causou espécie na época. A idéia é a seguinte: Rosemary, com o filho gerado pelo Diabo, afasta-se da seita, pois não concorda com a intromissão de seus membros na educação da criança, porque falavam em fugir da terra num disco voador, na cauda de um cometa, e ainda queriam fazer uma circuncisão radical no menino. Ela foge para a Escócia, casa-se novamente e o marido adota o gracioso menino que recebe o nome de Ian. Ele cresce, estuda e se torna um belo embriologista em Edimburgo. Embarca num projeto que, depois de 277 tentativas frustradas, consegue, sem os gametas masculinos, sem o sexo, através da proliferação controlada de células, gerar a ovelha negra que era branca. O título que sugiro para este filme é $O$ bebê de Rosemary's baby. Obrigado.

\section{Paulo Vaz}

O que me vem à cabeça, para pensar a clonagem, é a lembrança de que até há bem pouco tempo era costume as pessoas se reunirem para ouvir pessoas falarem sobre o futuro, falarem sobre o que ia ou podia acontecer. Esse futuro era a revolução, quase sempre. A gente se reunia para tentar saber quais os destinos do socialismo, do comunismo, como a revolução ia chegar, quanto tempo faltava etc. Acho curioso que um sociólogo - e é importante que seja um sociólogo inglês — tenha dito que a eleição do Tony Blair, o fato de os trabalhistas terem substituído os conservadores depois de 17 anos, era muito menos importante do que a Dolly. Entâo, eu pergunto, hoje a gente se reúne para falar daquilo que a ciência faz e nào mais para falar da revolução? Tentando pensar estas distintas relações com o futuro, apresento-lhes algumas considerações. É claro que são distintas as relações com o futuro, e creio que elas definem as diferenças entre as sociedades de ontem e de hoje. Quando vínhamos ouvir falar da revolução, um desejo habitava cada uma das pessoas que ouvia aquilo. Quando a gente se reúne para falar de Dolly, não é bem o desejo que nos habita. Embora eu torça pelo Deep Blue, isso também não é o normal. Diante do caso Dolly, as pessoas normalmente se inquietam. Esse é o sentimento que reúne as pessoas. E esta- 
belecem uma relação diferente com o futuro, que marca diferenças sociais. Creio que a experiência de futuro ou de tempo que havia no pensamento moderno - e isso vale para autores muito diferentes como Kant, Marx, Nietzsche, Heiddeger - era uma experiência que tomava o novo como valor. Num texto que escreveu à época que testemunhava o movimento iluminista na França, logo após a revolução francesa, Kant disse: o iluminismo é o estado de saída da humanidade pelo qual os próprios homens são responsáveis. Veja só como ele define o presente. O presente é saída de algo. Todo o ser do presente consiste na possibilidade de deixar de ser o que ainda é. E valoriza esse não ser mais aquilo que ainda é, porque aguarda, ansiosamente, que os homens deixem de ser menores e se tornem maiores. É como se nós reconhecêssemos que no presente há limites, os homens não são livres ainda, mas no futuro, quem sabe, deixaremos de ser limitados. Isso podia ser dito de um modo mais ou menos teórico. Ah, o homem vai deixar o reino da necessidade para ingressar no reino da liberdade. O futuro, ausência de limite, é a utopia. Esse novo desejado, ansiado tinha como seu conteúdo maior a transgressão dos limites experimentados no presente. A gente vivenciava as limitações mas também a possibilidade de sair delas. É nesse lugar mesmo que surge a experiência ética do indivíduo: tornar-se o que é. Esse dito é famoso, aparece em Goethe, é retomado por Nietzsche, tem origem, na verdade, em Voltaire. É um dito que permeou a ética moderna. Gostaria que vocês percebessem que tem a mesma estrutura da frase de Kant, remete à mesma experiência de tempo. Porque tornar-se o que se é, se isso é algo que devemos fazer por nós mesmos, significa que ainda não somos aquilo que somos, vamos ser no futuro. Portanto, somos pelo menos dois: aquele que estamos sendo e o que vamos ser, aquilo que somos e não somos. Estou brincando com a palavra ser, aqui, com a intenção de dizer que as pessoas experimentavam a si próprias como donas da possibilidade de se liberar, mas sendo, simultaneamente, recalcadas. $O$ indivíduo sentia-se compelido a lutar por sua liberação, e essa liberação equivalia a ser realmente. Uma palavra famosa que as pessoas usavam era 'assumir'. Significa isso: deixarmos de ser aquilo que os outros querem que sejamos, para sermos, enfim, o que nós somos. Nesse espaço delimitado pela palavra assumir, inscrevia-se a liberdade do indivíduo em relação à sociedade. Percebem em que sentido éramos dois? Esse duplo era constitutivo do pensamento moderno, a temática da alteridade, do futuro como alteridade. Quero dizer, portanto, que o pensamento moderno era caracterizado pelo futuro como diferença e liberdade, e pela presença da alteridade no presente. Cada um de nós seria dividido em consciente e inconsciente. Haveria dentro de nós uma parte louca, e outra que tenta controlar essa parte louca. Creio que era neste lugar mesmo que apareciam os filmes que Castiel mencionou como $O$ médico e o monstro, o vampiro que é o outro dentro de nós, o chupador de sangue que não trabalha, que atrai todas as mocinhas e tem uma sexualidade mais legal.

No pensamento moderno, além da temática da espera, do duplo, havia a tendência a se pensar a mudança como mudança social, passagem de uma cultura a outra. A gente esperava passar do capitalismo ao comunismo, por exemplo. Creio que esse pano de fundo desapareceu na atualidade. Temas como a dupla alteridade, a espera e a transformação social deixaram de ser pertinentes para descrever o que está acontecendo em nosso tempo, o modo como hoje se vive o novo. Em primeiro lugar, ele tem a característica 
"Estamos vivendo

uma

transformação

tecnológica, e é ela que determina quem vamos ser, o tipo de mudança por que vamos passar ... Estamos deixando de lado uma essência humana, estamos nos modificando." de não ser mais um novo feito pelos homens, ou que dependa da ação dos homens. Por exemplo, nós revolucionários, nós que lutamos para acabar com a ditadura ou alguma coisa do gênero. $O$ novo é feito pela ciência, então vem queiramos ou não. Na verdade, vem nos surpreendendo, e esse novo tecnológico que nos surpreende tem uma característica: a imensa aceleração. Se fôssemos definir hoje o que é cultura, já que, como bem disse Luiz Alberto, não há mais diferença entre matéria e vida e, tampouco, entre natureza e cultura, a única diferença que há é que a vida é um pouquinho mais acelerada que a matéria, e a cultura muito mais acelerada que a matéria e que a vida. Então, a diferença entre natureza e cultura, entre matéria e vida é de aceleração apenas. Como as coisas giram rápido nesse mundo em que a gente vive. Um modo fácil de perceber isso é através da noção de reciclagem. Já pensaram o que significa reciclagem de profissionais? Significa que o avanço tecnológico é mais rápido que a mudança individual. Se os indivíduos têm que ser reciclados, o novo tem essa característica paradoxal do dever. Antes, o novo era o lugar da espera, da realização; hoje, é o lugar onde se pronuncia o famigerado 'eu devo'. Um filósofo chamado Michael Serre afirma, quando fala da tecnologia: "O poder tecnológico passou a nosso encargo o que antes era uma tarefa própria a Deus." Na teologia medieval, no pensamento teológico, Deus escolhia entre mundos possíveis. Claro, sendo sábio e bom, escolhia sempre o melhor dos mundos. Tinha uma série inumerável de mundos, de seres para pôr em existência e escolhia os que iam dar a melhor combinatória. Isso que era a tarefa de Deus está cada vez mais se tornando nosso encargo. Pensem em silicone, cirurgia estética, tudo que a gente pode fazer só com relação à forma. Pensem também em engenharia genética, em transplante para ver como nosso corpo deixa o terreno da necessidade para se colocar cada vez mais ao alcance de nossa ação. Passamos a viver num mundo onde temos poder sobre o poder ser. Fiquei impressionado com aquela frase do Ballard, porque ele coloca uma espécie de tempo novo, onde a experiência do futuro não está lá, à espera, está aqui como pressão, velocidade, mudança radical e como escolha entre múltiplos. Se quiserem, a primeira diferença é a passagem do duplo ao múltiplo, da temática da alteridade à do múltiplo. Eu diria que é o fim do "médico e o monstro" e o início dos borgies. Porque os borgies são a própria multiplicidade, eles resistem a tudo. Muito mais legais do que nós. A segunda diferença com relação à modernidade é que não é a transformação cultural que realiza o homem.

Hoje estamos vivendo uma transformação tecnológica, e é ela que determina quem vamos ser, o tipo de mudança por que vamos passar, como disseram com muita clareza Castiel e Luiz Alberto. Não se trata mais de uma mudança de cultura e sim de que deixaremos de ser humanos, certo? Estamos deixando de lado uma essência humana, estamos nos modificando. E não tem jeito, é um ponto de não-retorno mesmo. Por fim, vou falar do tempo. Creio que a grande diferença na experiência de tempo que a gente vive hoje é, como disse Ballard, tudo estar ao nosso alcance. Num mundo onde tudo está ao nosso alcance, não existe mais limite, no presente, à ação humana. Pode existir daqui a dez, cinco anos, pode ser até a Copa de 1998 - e quem dera fosse com o Garrincha -, mas não existem limites ao que podemos fazer no presente. O limite vem do próprio futuro. Antes o futuro era o lugar do ilimitado, agora é o que pode limitar. 
“É preciso investir de novo em arte e tecnologia, arte e ciência, para que essa capacidade visionária que a arte tem possa voltar a servir à projeção de futuros."
Deixe-me contar-lhes o melhor: isso quer dizer que é um futuro do presente. $O$ que pode funcionar como limite às ações humanas é aquilo que esperamos que of futuro seja. O que ele vai ser depende do que o presente espera que ele seja. Nós todos nos tornamos especuladores. Vivemos este feedback entre presente e futuro. O que eu gostaria de colocar, aqui, como saudoso da revolução, da utopia, é que nada é pior do que só desejar fazer o limite, pensar o futuro na forma do risco, do temor. É inadmissível pensar o futuro assim, mirando a proibição. Foge ao humano, não vai funcionar, ainda que aconteça. Ao invés de querermos impor limites no presente à ação humana, tendo em vista apenas o risco, o medo, meu desejo é que pudéssemos, de novo, injetar o desejo no futuro. Se o futuro depende do que a gente espera que ele seja, está ao alcance de nosso desejo. Vamos, então, enveredar pelo desejo novamente, para que o limite à ação humana seja dado por aquilo que se espera que a sociedade seja. É preciso, outra vez, não temer o futuro, porque foram só estes os discursos que aconteceram quando se falou da Dolly - "Ah, novos Hitlers!" Ou, então, "Ah, um mundo de Carlas Perez." Não sabe quem é, a moça do tchan? Ela ganhou a eleição para a escolha da pessoa a ser clonada. O que pode funcionar como limite, no presente, ao que a gente faz é aquilo que se espera que o futuro seja. Então, que esta espera não seja o medo, que tenhamos a força de investir afetivamente no futuro, em projetos e, para tanto, debates como este são extremamente necessários, porque a ciência tem de se abrir à democracia. Já que ela faz a sociedade — como a gente está descobrindo - , que a sociedade possa discutir o que faz a ela.

Se a ciência muda a sociedade, que nós tenhamos o direito, o dever, de dizer aos cientistas: "Vocês vão fazer isso mesmo? Têm certeza? Como é que vai ser? Mas que clone? Por que a Carla Perez e não o Brad Pitt?", poderiam argumentar as mulheres. Em segundo lugar, é preciso investir de novo em arte e tecnologia, arte e ciência para que essa capacidade visionária que a arte tem possa voltar a servir à projeção de futuros. Acho que está precisando haver, agora, um Julio Verne da Dolly, para que o mundo se torne um pouco diferente, mais habitável. É isso.

\section{Susana Schild}

Estou muito satisfeita por recebermos aqui reflexões tão importantes. Há meses não se fala mais dos clones. Confesso que estou morrendo de medo do futuro e, depois desse papo, acho que vou ficar numa sala escura vendo filmes pelo resto da vida. Porque aqui se está falando do inevitável, do fim das diferenças entre o inanimado e o vivo, entre o presente, o futuro e o passado. Nem sei mais em que tempo estamos, nós aqui ainda mortais.

Platéia: Ninguém mais é mortal. É só fazer o clone...

\section{Susana Schild}

Mas meus valores sobre o tempo são tão retrógrados... Antigamente, a gente falava: caneta Parker é para sempre. Tem uma outra coisa de que se está falando também: é a diferença entre verdadeiro e falso. Na história de Frankenstein, a diferença entre o monstro e o médico era evidente. Mas em Blade Runner, por exemplo, quase não há diferença entre o verdadeiro 
"Achar que é possivel fazer um clone de um homem mau é não levar em conta a distinção necessária entre o que é reprodução de características morfológicas, somáticas, e vida mental, que tem estruturação muitíssimo mais complexa." e o falso. A mocinha, se é falsa, artificial, é tão bonita, tão interessante, que nem vale a pena investigar se é replicante ou não.

Antigamente, havia a grife, não é? Hoje há a vingança do camelô. Eu adoro! Rolex, no camelô, custa dez pratas, todo mundo tem. Não sei se tem uma vingança bíblica aí, em relação aos clones, porque ainda sou meio moralista, acho que o feitiço vira contra o feiticeiro.

Estas questões geram grande perplexidade, perda de referenciais, de valores, visões de mundo. Não sei se na história da ciência houve algum momento em que tantas questões fossem confundidas a tal ponto. Vamos abrir o debate, mas aviso: estou apavorada!

\section{Paulo Vaz}

Você está expressando apenas a parte do risco, não a parte do que você quer, pois há a oportunidade, também, de a gente colocar aquilo que quer. Certamente, não aconteceu o que se esperava quando houve a corrida espacial, mas pense quanto a sociedade mudou desde a pílula e o vírus da Aids, que são descobertas científicas. Esse é o exercício que tem de ser renovado, cada vez mais. A impressão que me dá é que a gente passa a viver um presente em que cada escolha recoloca o mundo inteiro, e o mundo inteiro significa milhões de simulações de futuro. O problema é quando você simula o futuro só a partir do risco, você o reduz, faz o exercício inverso ao que é necessário. Certamente assusta a perspectiva de se ter um bando de Carla Perez por aí. Fixação, não é? O problema é ficar fixado num certo futuro, quando é necessário imaginar vários. Nossa liberdade vai depender um pouco dessa capacidade de inventar mundos.

\section{Waldemar Zusman}

Gostaria de acrescentar um comentário a essa discussão sobre a clonagem, que teve repercussão muitíssimo persecutória, diria até paranóica, em todos nós. Acho que é porque avançamos pouco na discussão sobre a experiência que foi feita. A clonagem é uma reprodução muito mais biológica do que mental. Com ou sem relação sexual, nós não podemos fazer com que nasça um ser a partir de outro, com as características da personalidade deste. Podem ser fisicamente muito semelhantes, mas diferenciam-se enormemente no plano mental. Os gêmeos são uma experiência milenar, e nós sabemos como diferem uns dos outros. De modo que achar que é possivel fazer um clone de um homem mau é não levar em conta a distinção necessária entre o que é reprodução de características morfológicas, somáticas, e vida mental, que tem estruturação muitíssimo mais complexa. Se não levamos em conta esta diferença, colocamo-nos em posição de perseguidos pelo temor de que os indivíduos maus proliferem. Como sugere o livro Os meninos do Brasil, em que se imagina a possibilidade de se criarem cópias de Hitler. Ainda que os indivíduos nascidos de uma clonagem possam ser criados por pessoas com ideologia nazista, é preciso não esquecer que qualquer pessoa pode se tornar nazista sem precisar de clonagem. Então, ela não é o que se pensa atualmente. É reprodução de características somáticas, uma experiência feita em animal. As experiências da generalidade humana mostram o contrário do que as pessoas temem. Aliás, escrevi sobre essa distinção absolutamente necessária em $O$ Globo (6.3.1997). 
"A genética saiu da Academia e foi para as empresas privadas, que estão dando um banho, porque a Academia não tem como acompanhar 0 rigor delas..."

\section{Luiz Alberto de Oliveira}

Acho que o senhor tem toda a razão. Não se trata de clonar pessoas, no sentido de seres dotados de personalidade. Trata-se de uma manifestação do poder de intervir no nivel elementar da vida. Reportando-me novamente ao cinema, tomo, por exemplo, Arquitetura da destruiçào, filme fascinante que investiga a estética do nazismo. Ele coloca uma coisa em que nunca tinha pensado. O nazismo propõe a idéia de que a nação tem um corpo, que é o povo, e, assim como o corpo de um indivíduo, ele se fortalece, enfraquece, adoece ou se potencializa. Uma equação entre doença e feiúra aparece nas escolhas e propostas da arte nazista. Tais escolhas legitimam a identificação entre a medicina, que trata dos corpos, e a erradicação de pragas, a prática generalizada do extermínio. Além do fato, para mim insuspeito, de que o nazismo não é irracional, o que me impressionou muito no filme foram as possibilidades que se abrem para a nossa época. Ou seja, até que ponto faremos escolhas, digamos, estéticas. Uma criança descerebrada constitui, evidentemente, um fato horrível, tanto que consideramos moralmente justificável a interrupção da gravidez nesse caso. Mas até onde irá esse poder de escolla que, em princípio, todos nós vamos ter. Se terá orelhas grandes, se será alto, baixo, homem, mulher, vascaíno ou rubro-negro. Até onde irá a escolha? Deixá-la entregue apenas aos cientistas nos põe na antesala do fascismo, porque só um grupo detém as informações, o poder. Como Paulo frisou, é necessário que a ciência e suas inovações técnicas sejam debatidas democraticamente. Do contrário, toda a sorte de pesadelos vai ser possivel, assim como toda a sorte de glórias e grandezas, porque este é o momento de inventarmos novos modos de ser, e vamos ter que fazer isso, sejamos sábios ou não.

\section{Luis David Castiel}

Também acho que o dr. Zusman tem toda a razão. Agora, na manipulação genética, existem algumas idéias de base a que se deve prestar atenção. Uma delas é o projeto de aperfeiçoamento da natureza e, por extensão, do homem. Esta idéia reveste-se de uma série de metáforas triunfalistas, que supõem a possibilidade de reformar a natureza. Monteiro Lobato já abordou isso em uma das histórias protagonizadas por Emília. Que aperfeiçoamento é esse? E mais, que acesso vai ser possível ter a esse homem reprogramado? Quem poderá comprar o aperfeiçoamento? Na clonagem há, sem dúvicla, uma questão genética e uma questão epigenética. Uma diz respeito ao que é adquirido, a outra ao que é apreendido. Mas o programa de manipulação de DNA recombinante traz embutida a possibilidade de transgenicidade e de busca de um santo graal. Uma série de metáforas subjacentes ao projeto Genoma têm de ser desmontadas. É preciso parar de pensar que se está em busca do elixir da vida, da essência. Refiro-me à idéia de que, se você puder abordar o genoma de uma pessoa, pode purificá-la. Mas o que é essa purificação? E quem vai ter acesso a ela? É uma discussão recente das empresas biotecnológicas americanas. A genética saiu da Academia e foi para as empresas privadas, que estão dando um banho, porque a Academia não tem como acompanhar o rigor delas. E há uma questão ética aí, já que todas as descobertas delas vão ser patenteadas. No horizonte próximo estão os medicamentos programados, pois uma série de problemas genéticos são passiveis de tratamento por medicamentos que agem imunologicamente. 

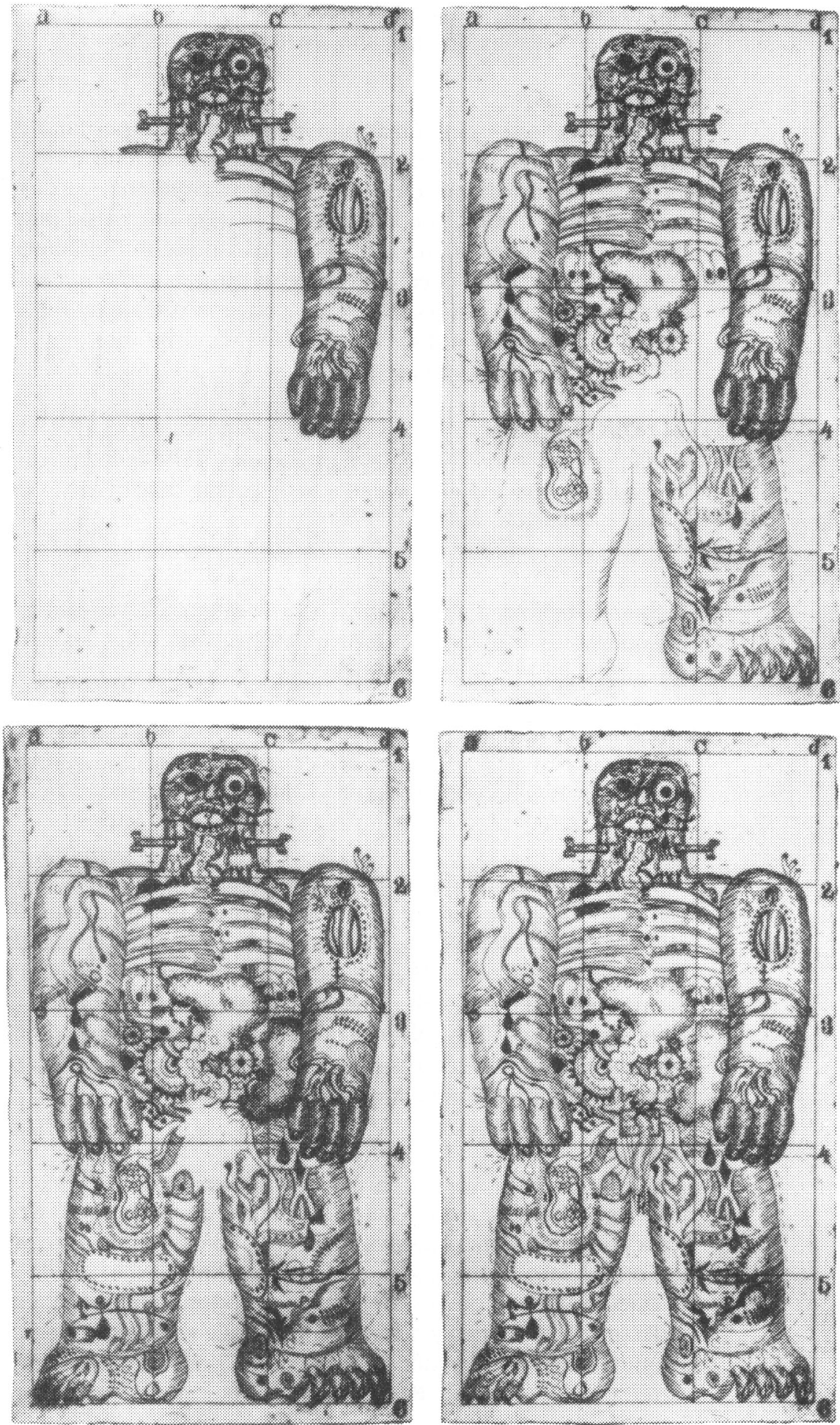

Pranchas desenhadas por Uwe Bremer para ilustrar uma tradução alemã de Frankenstein de Mary Shelley. (Franz Rottensteiner, La science fiction illustrée. Une histoire de la S. F. Paris, Seuil 1975, p. 32.) 
O coquetel da Aids já é produto dessa rede. A clonagem é apenas a ponta do iceberg no âmbito do programa de manipulação genética.

\section{Platéia}

A meu ver, estes problemas não impedem que a pesquisa continue. É bem verdade que, numa primeira fase, quem tiver mais poder aquisitivo terá acesso primeiro, mas, como todo produto da indústria - a da informática, por exemplo -, começa com um preço e para um grupo pequeno, mas depois se dissemina. Acho que o que não pode é a clonagem tomar o caminho da discussão ética, porque se vai purificar isso ou aquilo, tem-se medo do futuro, ou porque "vai ser só para gozo de um milionário"...

Não se pode frear a discussão, e ela tem mesmo que ser democrática, mas a pesquisa precisa prosseguir.

\section{Luis David Castiel}

Não resta dúvida de que deve prosseguir. Mas a indústria de alimentos, por exemplo, com todos os avanços, não garante disseminação generalizada de seus produtos.

\section{Platéia}

Isso não é problema da indústria, nem da pesquisa. É um problema político. Nada tem a ver com a capacidade da indústria de biogenética de produzir alimentos melhores, mais nutritivos.

\section{Luis David Castiel}

Não quero me colocar numa posição obscurantista, pois estou do lado da pesquisa, mas acho que a coisa não é tão tranqüila assim...

\section{Paulo Vaz}

Também acho... O que se está questionando não é a relação do cientista com seu objeto de pesquisa, é a relação da pesquisa científica com a sociedade. O problema da pesquisa feita por empresa é que ela não funciona para a felicidade geral, sobretudo num país onde três quartos da população vive na miséria. Eu não tenho muita esperança de que o mercado universalize os seus frutos, por mais universal que ele seja. Reconhecer isso não significa colocar-se contra as empresas ou os cientistas. Trata-se de saber como a sociedade pode agir sobre aquilo que vai ser.

\section{Platéia}

Questões de clonagem, mapeamento genético para fins capitalistas, tudo isso são coisas que estão ocorrendo e com que a gente deve se preocupar. Estou mais preocupado em contextualizar a imagem que se tem do artefato tecnológico, a imagem cultural. Estão sendo publicadas revelações sobre o projeto Genoma que contrariam aquele temor de que pudesse revitalizar a eugenia. Ao contrário, ele vem reforçando a convicção de que a diversidade genética é algo muito poderoso, inclusive enquanto barreira contra doenças. Penso que o uso que se vai fazer das tecnologias depende da representação que se tem delas. Ou seja, neste mundo em que vivemos, preocupa-me a noção de que a história acaba, há um fim se avizinhando, tudo começa hoje. 
Pensem na aceleração do tempo, na evolução cósmica, evolução biológica, evolução cultural... São milhões e milhões de anos, um passado que dificilmente se vai conseguir reproduzir em laboratório. Não se tem, e nunca se terá, controle em laboratório sobre questões pertinentes ao acaso, que interferem profundamente, por exemplo, na formação do clone. Preocupame, realmente, essa idéia de fim das coisas e começo de tudo, de que a clonagem vai fazer o homem melhor. Porque serve a uma idéia de mundo e a um tipo de política calcados no darwinismo social. Enquanto a mídia martela a idéia de que o clone é a melhor coisa, de que a tecnologia vai melhorar o mundo, você vê, no continente africano, milhares de pessoas morrerem todos os dias de conflitos, fome, abandono... Isso precisa ser criticado, porque, mesmo em termos técnicos, é absolutamente equivocado. É preciso contextualizar a idéia de que a tecnologia representa, sobretudo, um avanço. Coisas estão se abrindo, mas os sentidos delas ainda são muito relativos...

\section{Susana Schild}

É interessante como a arte, a criação cultural, parece ter sido muito mais visionária do que a ciência. Por exemplo, Blade Runner. Qual era a possibilidade científica que havia para se fazer uma ficção dessas? Ou 1984, de George Orwell, e outras criações cujos autores se deixaram tomar pela imaginação. Não sei se a ciência tinha esse poder visionário. Pensava-se no século XVIII que no final do XX ia ter gente fazendo clone? A arte, até certo ponto, pensou isso, não? Como sou da área cultural, tento responder às minhas perguntas através das manifestações dela, já que não tenho acesso ao discurso científico. Então, por exemplo, Woody Allen, em O dorminhoco, aquele filme em que fica congelado cinqüenta anos, e quando acorda, diz: "Gente, eu operei a garganta e acordei devendo cinqüenta anos de aluguel."

\section{Luis David Castiel}

A propósito desse aparente ou real antagonismo entre ciência e arte, lembro que houve uma época em que as pessoas eram tudo junto: cientistas, artistas, filósofos, poetas. O exemplo típico é Da Vinci. Mas, num certo momento, separaram, o cientista embicou para a ciência, o artista para outro lado...

\section{Platéia}

Eu estava pensando na divisão que normalmente se faz entre pesquisa científica e ética. Quando lia Frankenstein chamou-me a atenção um detalhe curioso: ele era aquele médico que queria descobrir os segredos da vida e da morte. Ficava extasiado com as descobertas, mas era um sujeito de poucos amigos. Tinha um amigo íntimo que se interessava pelas questões da moralidade. Eles foram separados pelo desejo do pai do amigo, que o proibiu de estudar, já que era comerciante e achava perda tempo e de dinheiro ser intelectual. Só voltam a se encontrar depois de Frankenstein produzir sua criatura. O descompasso sugere a idéia de que as questões éticas não acompanham os avanços da tecnologia. Por outro lado, o que teria acontecido se Frankenstein tivesse sido capaz de se responsabilizar eticamente por seu ato? Porque o monstro só se torna monstro ao ser renegado pelo criador. Então recorro à palavra 'assumir', e pergunto: se ele tivesse assumido seu ato, qual teria sido o desenrolar da história? Em relação à questão do medo, 
“A clonagem não

é a grande

novidade: é um susto endereçado

a pessoas

assustadas." lembro que, desde a mitologia, sempre que o homem tenta invadir um território demarcado como sendo dos deuses advém o castigo. Prometeu ficou acorrentado anos e anos, tendo o seu fígado roído. Inclusive, pelo que sei, desapareceu a última parte da trilogia do mito, que seria aquela em que Prometeu se liberta do castigo. Eis, então, o que eu queria colocar: tendo em mente esta coisa que se repete na mitologia, na ficção científica - a gente pode pensar como forma de mitologia contemporânea -, como pensar a possibilidade de uma elaboração em que as conseqüências de um ato não sejam vividas como um castigo, mas possam ser assumidas, sei lá, no âmbito de uma ética trágica?

\section{Waldemar Zusman}

É possível definir o homem de muitas maneiras. Uma definição apropriada ao debate em curso é que o homem é um animal transgressor, e a ciência, o exercício constante das transgressões, não só de limites naturais, mas também éticos. Esse é um aspecto da evolução humana que nunca vamos deter. Nem os homens primitivos, que não fazem grandes transgressões, ficam dentro do território que conquistam, onde extraem alimentos e inventam pouco ou nada.

A questão da clonagem não me parece uma transgressão tão grave. Nós fazemos isso com as plantas, no mundo vegetal a clonagem é uma constante. Entre os animais inferiores, há reprodução assexuada por divisão, por cissiparidade. A clonagem não é a grande novidade: é um susto endereçado a pessoas assustadas. A pior manipulação, aquela que mais se deve temer, não é tanto a genética, porque esta tem limites, e sim a manipulação ideológica. Há pouco se disse que há uma concepção de mundo incluída nos conglomerados comerciais que produzem drogas. Ideologia é, essencialmente, uma concepção de mundo que veiculamos para o outro. Manipular o pensamento do outro, introduzir nele uma concepção de mundo, é aquilo que verdadeiramente devemos temer. O ser nascido da manipulação genética depende sempre da manipulação ideológica para se tornar um representante do mal, e o que é o mal senão puro pensamento maniqueísta?

\section{Paulo Vaz}

Creio que o mal, hoje, é alguém acreditar que pode dizer o que deve ser o futuro, é alguém pretender se apossar da verdade acerca do que é bom para o homem. E esse mal tornou-se pior porque, de certo modo, hoje a ciência faz a sociedade. Daí, eu repito, é preciso discutir a ciência para pensar a sociedade - não há mais como distinguir uma e outra. Essa é uma questão ética: como lidamos com aquilo que irrompe em nossas vidas, em nosso pensamento, e perturba o que tínhamos de tão certo. Quando mirávamos a revolução ou olhávamos para o passado - invoco aqui aquela frase linda de Walter Benjamim - , buscávamos ver toda a esperança de salvação não realizada para tentar fazer a história dos vencidos. Estava em jogo a luta dos homens por sua liberdade. Hoje fazemos tentativas de reduzir a aspereza deste novo que provém da tecnologia. Fatos eruptivos, ásperos, inquietam, obrigam a repensar certezas, tudo aquilo que era familiar. Desde que o homem é homem, ele tem medo de seus artefatos técnicos, de suas criaturas. O convite que eu faço, convite de filósofo, é para repensarmos as nações familiares que tínhamos a respeito do homem, sem tentar reduzir a aspereza do novo. 


\section{Luis David Castiel}

Não sou da área de ética, mas gostaria de lembrar que existem dois tipos: a ética cotidiana, referida, por exemplo, à deontologia médica, à relação médico-paciente, uma ética, enfim, de coisas familiares; e a ética das coisas aceleradas - chamo ética de fronteira - , que está correndo atrás das coisas que estão sendo produzidas. Ela não acompanha pari passu proliferação tão grande.

Gostaria de comentar também a questão ideológica. Tem ideologia da genética assegurando que os problemas são passíveis de resolução mediante técnicas neurogenéticas. Na Ciência Hoje foi publicado artigo de S. Rose (1997) sobre o determinismo em neurogenética, chamando a atenção para a exacerbação de explicações biológicas para um sem-número de fenômenos com seus respectivos medicamentos. O mau humor, por exemplo, virou doença. Já tem outro nome, distimia, tem até remédios, mesmo que seja distimia engarrafada. É difícil não ficar mal-humorado num engarrafamento, não é? Portanto, é verdade que a ideologia é um problema, mas há a ideologia da genética, e ela está se ampliando cada vez mais. Os problemas passam a ser equacionados mediante abordagens biológicas. Steven mostra que há projetos de se investigar as anomalias do DNA dos negros americanos para ver onde está a série da violência. É na verdade um projeto antigo, que vem de Lombroso, do estudo das fisionomias, e que se atualiza graças a este modelo de determinismo da neurogenética, da ideologia da genética. A gente tem que estar atento a isso.

\section{Luiz Alberto de Oliveira}

Vou tentar exprimir um sentimento que o nosso diálogo suscitou em mim. A terceira etapa do mito de Prơneteu seria o herói libertado por Hércules. Este arrebentaria os grilhões de seu tio-avô (Prometeu era tio de Zeus, pai de Hércules). Bem, Hérçules me parece ser a figura da ação humana, ou super-humana, a representação do homem como ser que desliza e não como algo que está acabado. Hércules, então, é aquilo que o espírito humano produz: filosofia, ciência e arte. Estes são os instrumentos que nossa história nos legou, são as forças de que dispomos, são a potência de nosso corpo e nossa alma para empreendermos esta jornada. Não podemos é recolher as velas...

\section{Luis David Castiel}

...ou acender as velas... 


\section{Histórico da clonagem}

1886 Leis sobre a hereditariedade de Mendel

1984 Primeiro nascimento humano a

1890 Primeiros nascimentos - de coelhos - por transferência de embriões partir de embrião congelado

1949 Primeiro congelamento de esperma de touro

1951 Primeira transferência de embriões para uma vaca

1952 Primeiro vitelo originado por inseminação artificial Primeira clonagem de rã (células embrionárias) Primeiras plantas regeneradas in vitro

1953 Primeira inseminação artificial no homem

1954 Primeira fecundação in vitro de coelho

1962 Primeira clonagem de sapo (células diferenciadas)

1970 Primeira planta regenerada a partir de protoplasma

1972 Primeiro camundongo nascido de embrião congelado

1973 Primeiro vitelo nascido de embrião congelado Identificação do plasmídeo Ti (Tumor inducing/indutor de tumor)

1976 Diagnóstico pré-natal por sonda de DNA

1978 Primeiro gene humano identificado Primeiro bebê de proveta

1979 Primeiros cordeiros gêmeos obtidos por cissão de embrião Insulina produzida por engenharia genética

1985 Primeiro mamífero transgênico Primeira planta transgênica resistente a um inseto

1986 Primeiros clones de mamíferos (células embrionárias)

1987 Primeiro camundongo transgênico com leite modificado (uso farmacêutico) Primeira linhagem de camundongos 'humanizados'

Primeira planta transgênica resistente a um herbicida

1988 Primeira ovelha 'farmacêutica' Primeira planta 'farmacêutica' Primeiro cereal transgênico (milho)

1990 Desencadeamento do Projeto Genoma Humano

1991 Primeira triagem de embriões Primeiro DNA medicamento (terapia gênica) Identificação do gene SRY (masculinidade)

Primeira vaca 'farmacêutica'

1992 Primeira injeção intracitoplásmica de espermatozóide

1994 Primeira fecundação in vitro de planta (milho)

Primeiro fruto transgênico comercializado

1995 Primeiro bebê gerado a partir de um ovócito e um espermatozóide

1981 Primeiros camundongos transgênicos

1996 Primeiro enxerto xenogênico de coração de porco 'humanizado' num babuíno

1982 Camundongo gigante obtido com hormônio de crescimento de rato Primeiro nascimento por fecundação in vitro de uma vaca

1997 Anúncio do nascimento de Dolly Primeiros clones de primata (cissão de um embrião)

1983 Primeira mãe inseminada artificialmente Primeira planta transgênica (tabaco) Primeiro tabaco produtor de hemoglobina

Estes marcos foram encadeados por Marie-Laurent Moinet em 'Un siècle de manipulations'. Science \& Vie, n 956, mai. 1997, pp. 88-91. Gravura estampada na edição alemã de Nicolai Klimii iter subterraneum, do barão Ludvig Holberg (1828). (Franz Rottensteiner, op. cit., p. 76.) 


\section{Paulo Affonso Leme Machado}

Primeiramente, o Brasil é um estado democrático de direito e tem a dignidade humana como um dos seus fundamentos. Isto está na Constituição Federal, art. $1^{\circ}$, inciso III.

Dignidade humana não é, portanto, um ornamento. Ela é produto de uma verdadeira alfaiataria jurídica no âmbito da Constituição, que relaciona diversos deveres e direitos. As constituições escritas são os instrumentos que os povos utilizam para estruturar seus países. Constituem uma espécie de contrato, de pacto social subscrito pela maioria das pessoas, de forma direta ou através do sistema representativo. Todas as constituições modernas têm insistido sobre a valorização da dignidade do homem.

Acredito que seja apropriado buscar nos dicionários o conceito de homem. O de Aurélio Buarque de Holanda Ferreira registra 14 acepções. Chamo atenção para duas. A que ressalta a condição de ser humano, com sua dualidade de corpo e espírito, virtudes e fraquezas e a acepção biológia que singulariza cada um dos indivíduos da espécie Homo sapiens, única existente da família dos homíneos, do gênero bomo, da ordem dos primatas, dos mamíferos - espécie esta que ocupa posição especial na natureza, em virtude de suas funções diferenciadas, volume do cérebro, uso da linguagem articulada e desenvolvimento da inteligência, abstração. Se olharmos outros dicionários, em diversas línguas, veremos que a definição biológica tem a mesma formulação.

Essas conceituações encontradas tanto nos dicionários quanto nas constituições não tocam, em sua forma de origem, se a reprodução é sexuada ou assexuada. Contudo, segundo o entendimento comum, o ser humano provém da união sexual de um homem e uma mulher, ocorrendo a fecundação do óvulo, pelo espermatozóide, seja de que modo for. $\mathrm{Na}$ parte jurídica, o ser homem ou mulher é o objeto de defesa das constituições. Estas lhes garantem a honra (arts. $5^{\circ}$ e $10^{\circ}$ da Constituição Federal), protegem-nos da tortura (art. $5^{\circ}$, inciso III da Constituição Federal), ainda que também os animais sejam protegidos da crueldade (art. $225^{\circ}$, parágrafo $1^{2}$, inciso VII).

A Declaração do Rio de Janeiro, de 1992, não foi naturocêntrica, mesmo tendo se preocupado com o meio ambiente. Ela foi antropocêntrica ao afirmar que os seres humanos estão no âmago das preocupações com o desenvolvimento sustentado, e que têm direito a uma vida saudável e produtiva, em harmonia com a natureza.

O homem está protegido pela Constituição brasileira dentro ou fora da família, que é considerada a base da sociedade. A entidade familiar é a união estável do homem e da mulher, como também a comunidade formada por qualquer dos pais e seus descendentes (art. $10^{\circ}$, parágrafos $3^{\circ}$ e $4^{\circ}$ ).

Volto agora ao dicionário anteriormente citado, e encontro o termo clone definido como produção assexuada dos descendentes de uma única planta ou animal, ou, ainda, como o conjunto de indivíduos originários de outros por multiplicação assexuada. Consta também que todos os membros de um clone têm o mesmo patrimônio genético. Faço notar que, nessas definições, não aparece a noção de filhos, e, por terem o mesmo patrimônio genético, os clones são iguais, ainda que se possa admitir o desenvolvimento deles em ambientes diferentes. Assim, entendo que o clone originário do homem ou da mulher não foi previsto na legislação brasileira. 
"A clonagem de vegetais e animais, sem uma legislação regulamentadora específica, fere $\circ$ princípio constitucional brasileiro, que obriga o poder público a preservar a diversidade do patrimônio genético do país ..."
Como terceiro ponto, trago a discussão jurídica do clone na espécie humana. Preliminarmente, a realização de clones, sejam eles vegetais ou animais, implica repetição de patrimônio genético, e este aspecto merece ser aprofundado sob o prisma do direito ambiental internacional e do direito ambiental constitucional brasileiro.

Aqui é interessante recapitular o conceito de diversidade biológica constante da Convenção da Biodiversidade: "é a variedade dos organismos vivos de qualquer fonte, incluídos entre outras coisas os ecossistemas terrestres e marítimos e outros ecossistemas aquáticos e os complexos ecológicos de que fazem parte". Assim, a diversidade biológica compreende a diversidade dentro de cada espécie, entre as espécies e entre os ecossistemas.

Inegavelmente, a produção de clones reduz a diversidade dentro de cada espécie, ao introduzir a unicidade de patrimônio genético. Parece-me que a clonagem de vegetais e animais, sem uma legislação regulamentadora específica, fere o princípio constitucional brasileiro, que obriga o poder público a preservar a diversidade do patrimônio genético do país (art. 225\%, parágrafo $1^{2}$, inciso II da Constituição Federal). Estamos praticando a clonagem de vegetais já há longo tempo, como eu em indústrias do Espírito Santo, sem que haja regulamentação específica para isso.

A lei n̊ 8.974 , de 5.1.1995, não se aplica quando a modificação genética for obtida através de técnicas por ela enunciadas (art. $4^{\mathrm{e}} \mathrm{e}$ incisos), "desde que não impliquem a utilização de organismo geneticamente modificado (OGM) com receptor ou doador: I. mutagênese; II. formação e utilização de células somáticas de hibridoma animal; III. fusão celular, inclusive a de protoplasma, de células vegetais que possa ser produzida mediante métodos tradicionais de cultivo; IV. autoclonagem de organismos não patogênicos que se processe de maneira natural".

Sobre o experimento de clonagem da ovelha Dolly, o presidente da Comissão Técnica Nacional de Biossegurança (CTNBio), dr. Luiz Antonio Barreto de Castro, enviou ofício ao ministro da Ciência e Tecnologia, em 6 de março de 1997, de onde destaco a seguinte parte: "Como o oócito foi enucleado e nele introduzido o núcleo de outra célula para possibilitar a experiência, este processo constituiu, portanto, uma manipulação genética de célula germinativa."

A manipulação genética de células germinais humanas está proibida na lei $\mathrm{n}^{2}$ 8.974/95 (art. $8^{\circ}$, inciso II). O descumprimento dessa proibição caracteriza uma infração administrativa (art. 119), podendo acarretar ao infrator multas, paralisação da atividade e interdição do laboratório ou da instituição responsável (art. $12^{2}$, parágrafo $2^{2}$ ). Sou favorável à criminalização dessa atividade, mas para tanto é preciso a inserção da pena no art. $13^{\circ}$, inciso I cla mencionada lei.

Quando há definição de crime numa lei, em cada inciso dela há a descrição do comportamento; e acoplada à descrição está a pena. Ou então a pena poderia ficar no final, quando diriamos que ela iria valer para todos os incisos. Mas, por questões que não posso atinar, quando a lei $n^{9} 8.974$ fala na proibição da manipulação das células germinais, a pena não foi acoplada.

Dito isto, como o que me traz aqui é o levantamento de questôes, suponho ad argumentandum que haja viabilidade técnica de fazer-se um clone a partir do ser humano, e pergunto:

1) O clone surgido seria "homem" ou teria outra qualificação? 
2) Quem abrigaria o embrião do ser humano clonado? Essa pessoa, que direitos e deveres teria para com o clone e para com a sociedade?

3) O clone estaria abrangido pela proteção dos direitos humanos ou seria necessária a previsão de uma nova proteção legal desse ser?

4) O clone poderia fazer cruzamento com um homem ou uma mulher? Quais as conseqüências jurídicas?

5) O ancestral do clone (ser humano) teria obrigações jurídicas para com os clones dele advindos, como o dever de assistência material e moral e o dever de representação até sua maioridade?

6) Qual o relacionamento jurídico do clone para com seu ancestral de forma a evitar-se a criação de um grupo de súditos ou até de escravos clonados?

7) Os clones seriam submetidos às mesmas regras de responsabilidade $\mathrm{e}$ de imputabilidade vigentes para os seres humanos?

Até sob o ponto de vista filosófico e teológico penso que seja importante perguntar se o clone teria espírito ou alma? E que a questão não deve ser desprezada, pois, quando portugueses e espanhóis chegaram à América do Sul, pretenderam escravizar os índios, sob a alegação de que eles eram desprovidos de alma. Também não haveria o perigo de considerarmos o clone do ser humano um cidadão ou cidadã de segunda classe ou de uma superclasse?

A liberdade de pesquisa, como todas as manifestações de liberdade, não constitui um direito isolado. Interliga-se com os direitos à vida, à propriedade, à segurança enunciados em todas as constituições brasileiras. Portanto, a liberdade da atividade científica é um direito individual (constante do art. 5, inciso IX, da Constituição Federal), e, como todos os outros direitos arrolados, está sujeita aos fundamentos e aos objetivos da República Federativa do Brasil, nos quais estão a dignidade humana e a construção de uma sociedade livre, justa e solidária (artigos $1^{2}$ e $3^{\circ}$ ).

Penso que, enquanto estas questões jurídicas não forem solucionadas, a realização de clones advindos do ser humano contraria a Constituição Federal.

\section{Marli de Albuquerque}

Lucian Sfez escreveu um dos primeiros livros de impacto sobre a grande utopia do século XXI que está sendo preparada no mundo em que vivemos - o projeto da saúde universal possibilitada pela biotecnologia. Questões importantes começam a se desenhar em nosso século, onde a forma (estética) está associada ao imaginário do 'homem modelo', do portador da 'saúde perfeita'. Se juntarmos as peças-chave dessa ideologia, perceberemos que, na prática, já temos em 'linha de produção' vários projetos que contemplam a 'grande saúde' do 'homem perfeito', como é o caso do projeto do mapeamento, genético. Certamente, este mapeamento, aplicado à saúde, traz benefícios, como a produção de insulina, por exemplo. No entanto, existe um grande mercado para a comercialização desses benefícios, através do patenteamento genético, o que realça o poder da nova ideologia da ciência.

Tal preocupação levou a Organização das Nações Unidas para Educação, Ciência e Cultura (Unesco) a propor a discussão sobre uma 'Declaração dos Direitos do Genoma Humano'. Explicita a necessidade de reconhecer o genoma humano como patrimônio comum da humanidade. Destaca o 
equilíbrio dinâmico que deve haver entre a garantia dos direitos inalienáveis da pessoa humana e o interesse comum da humanidade. Afirma a liberdade de escolha contra eventuais intervenções sobre o genoma da pessoa e a confiabilidade dos dados individuais frente à cobiça ou ao interesse de terceiros.

O debate maior que está embutido nesse documento diz respeito ao risco de se consolidar uma 'lógica' instrumentalizada que venha a justificar a associação da pesquisa do genoma humano com a 'lógica' da utilização e disponibilidade dos recursos econômicos.

Sabemos das denúncias sobre contrabando de órgãos humanos, camuflado em processos de adoção de crianças dos países pobres. Tais fatos jamais foram devidamente apurados. Quais são as garantias que se dá ao genoma humano para protegê-lo das sondagens inspiradas por interesses econômicos, sobretudo da partilha do mundo, que continua a ser feita pelos países dominantes?

O documento que a Organização das Nações Unidas (ONU) enviou, entre maio de 1995 e janeiro de 1996, a algumas instituições, personalidades científicas e organizações não-governamentais (Ongs) aponta duas dificuldades importantes: o crescente sigilo das pesquisas no âmbito das instituições e os embaraços criados à propriedade intelectual sobre o trabalho. Retoma-se, assim, uma questão jurídica clássica: o direito de patente recai sobre as invenções, mas no domínio da genética é tarefa complexa definir o que é invenção e o que é descoberta.

Outra questão colocada pelo documento situa-se no plano ético. O debate é aqui bem mais evidente e direto. Fatos mostram que pessoas têm sido forçadas a se submeter a testes genéticos; a marinha norte-americana tem utilizado marinheiros para isso, e as empresas de seguro saúde vêm praticando os testes para calcular sua margem de riscos.

Falamos nas peças-chave que compõem o projeto da busca do homem perfeito, ou a busca da utopia dos superseres. Lembramos que a vulgarização das práticas da fertilização artificial, as técnicas de conservação de óvulos e espermatozóides, de mapeamento de cromossomos, as estimativas dos genes e das doenças a eles associadas, que indicam predisposições, já são técnicas disponíveis na maioria dos consultórios médicos dos países desenvolvidos.

Não queremos dizer que a ciência deve ser fechada em uma camisa-deforça, pois o processo científico é irreversível. Queremos apenas enfatizar a necessidade de uma reflexão profunda sobre as práticas científicas associadas à manipulação genética.

Finalizo evocando o feto de Chernobyl e o quadro O grito, do pintor norueguês Edvard Munch. Ambos exprimem a angústia humana. $O$ feto foi vítima de um acidente, embora a usina tenha sido obra da tecnologia de ponta supostamente elaborada em benefício do homem. As imagens refletem a cruel imitação entre vida e arte. Se não houver uma aproximação de fato entre ciência e sociedade, ao invés do progresso da existência humana teremos o crescente enclausuramento do homem em suas próprias angústias.

\section{Win Degrave}

Preliminarmente, gostaria de lembrar que clonagem não é um fenômeno totalmente novo. Experimentos com animais já foram feitos há bastante tempo, usando-se células de sapos.

No ano passado, foi publicado sem muita notícia na mídia o primeiro artigo sobre a clonagem de uma ovelha pelo mesmo grupo. Usaram células 


"Acredito que
será possível
aperfeiçoar o
processo de
modo a dispensar
o uso do óvulo.
Ou seja, seria
possível
reprogramar a
célula diferenciada
e conferir-lhe toda
a potência, para
que se
diferenciasse da
estaca zero até o
ser completo."

"Acredito que será possíve aperfeiçoar o processo de modo a dispensar o uso do óvulo. Ou seja, seria possivel reprogramar a célula diferenciada e conferir-lhe toda a potencia, para que se diferenciasse da ser completo." embrionárias e fizeram a fusão de uma célula reprogramada com um óvulo sem núcleo. No experimento desse ano, usaram uma célula diferenciada, uma célula de um animal adulto, seguindo quase que exatamente o mesmo procedimento técnico.

Concomitantemente saía nos Estados Unidos o relato de clonagem a partir de células embrionárias de macacos. A opinião pública se manifestou por causa do uso da célula mamífera diferenciada, que chega perto da possibilidade de clonagem humana, e com a clonagem dos macacos, que demonstra que, tecnicamente, não há muita diferença entre uma ovelha e um primata.

Ainda há muita excitação sobre o processo porque foram quebrados dois dogmas da biologia celular. Primeiro, uma célula diferenciada pode ser reprogramada, retornando, vamos dizer, à estaca zero de diferenciação. Podese fazer isso com métodos extremamente simples. Suprimindo-se a nutrição da célula durante alguns dias, ela pára de crescer e volta a um estágio de multiplicação zero. O que acontece na estruturação genômica ninguém realmente sabe. Segundo, partindo-se de uma multiplicação assexuada, conseguiu-se chegar a um ser aparentemente completo, sem nenhum defeito aparente, quando todos os seres superiores na natureza usam obrigátoriamente o processo sexual para se multiplicar.

Considero, pois, que a excitação científica tem fundamentos, porque a experiência traz muita novidade na área da embriogênese e da diferenciação celular. É necessário e muito importante continuar nesse caminho de estudo. Estas são duas áreas que com certeza vão ter um desenvolvimento considerável nos próximos anos.

Não sei em quanto tempo, mas acredito que será possível aperfeiçoar o processo de modo a dispensar o uso do óvulo. Ou seja, seria possível reprogramar a célula diferenciada e conferir-lhe toda a potência, para que se diferenciasse da estaca zero até o ser completo. Pode-se prever, também, que o processo de clonagem ganhará eficiência suficiente para que se possa pensar na sua aplicação em seres humanos.

Em alguns países, laboratórios talvez estejam tentados a experimentar a clonagem de seres humanos, mas, no Brasil, creio que nos próximos dois ou três anos não há esse perigo, porque tecnicamente não é tão simples assim. Temos algum tempo para discutir e analisar os aspectos de legislação e regulamentação.

No que se refere a animais, sou de opinião que a clonagem não deve ser proibida, porque as aplicações são interessantes do ponto de vista científico, e bastante vantajosas do ponto de vista econômico. A clonagem pode ser usada para estudo de embriogênese e para a produção de animais transgênicos ou não transgênicos para a pesquisa. Vimos, por exemplo, que uma das vantagens da clonagem dos macacos foi fazer animais isogênicos - geneticamente iguais, idênticos — para testar vacinas.

Pode também ser aplicada na reprodução de animais geneticamente modificados, destinados à obtenção de órgãos para transplante, produção de fármacos ou realização de experimentos científicos. Penso, por exemplo, em animais que mimetizem alguma doença humana e que, a partir da clonagem, possam ser reproduzidos assexuadamente, em grande quantidade, para estudo. A indústria teria interesse em multiplicar animais, transgênicos ou não, que fossem grandes produtores de carne ou leite, ou mesmo cavalos de corrida excepcionais. 


“Posso imaginar
alguns
argumentos em
favor da clonagem
de seres
humanos: ... um
casal que tem
$100 \%$ de
probabilidade de
ter um filho com
sério defeito
genético pode
corrigi-lo assim."

Obviamente, como já foi mencionado, há o perigo de diminuir a diversidade biológica. Se isto é desatroso ou não, só saberemos com o passar do tempo.

Todo processo visando liberação de OGMs - plantas, animais, microrganismos, futuramente humanos — passam necessariamente pela Comissão Nacional de Biossegurança, que o analisa tecnicamente.

Posso imaginar alguns argumentos em favor da clonagem de seres humanos, mas não descarto a hipótese de vir a ocorrer o que chamo de desejo abusivo de clonar, com fins escusos, o que seria realmente problemático. Considero a clonagem vantajosa para resolver problemas de fertilidade, o que não é necessariamente um fim escuso. Outra possibilidade seria a dos clones corrigidos: um casal, por exemplo, que tem $100 \%$ de probabilidade de ter um filho com sério defeito genético pode corrigi-lo assim.

Os clones engenheirados teriam por objetivo não a correção, mas o melhoramento genético. Nesse momento, a diferença entre correção de defeito e melhoramento genético é relativa, mas num futuro próximo não vai ser, pois estou certo de que muito em breve serão detectados os genes responsáveis pela memória, pela estimulação cerebral, pelo bom e mau humor etc. Um dia poderemos pensar em simplesmente melhorar a memória de todo mundo. Por que não?

Sobre a legislação não vou falar muito. Acho que existem várias abordagens possiveis. A CTNBio escolheu, ou está escolhendo, um caminho dentro do seu escopo de trabalho. Há outros projetos de lei em andamento, e sem dúvida todas as comissões de ética que têm a ver com o assunto deverão ser incluídas nesta discussão. Assim, não vai faltar legislação sobre o assunto.

Gostaria de concluir com mais duas obsevações. Em primeiro lugar, discordo do dr. Paulo Affonso quando ele questiona se o clone será um ser humano. Em termos de direito, não vejo diferença entre o bebê de proveta e o clone. O problema mais sério é, obviamente, que o clone não terá genoma próprio, e isto vai contra a idéia de sermos únicos - o que pode ser bom, mau, ou uma mistura de uma coisa e outra. Mesmo assim, o clone não teria menos direitos por ser geneticamente idêntico a alguém. Em segundo, a ciência sempre conseguiu regular, razoavelmente, em termos éticos, o objeto do seu próprio estudo. A aplicação da ciência é sempre feita em conjunto com a sociedade e, geralmente, sob encomenda de setores dela. O problema é que as discussões éticas sempre correm muito atrás do desenvolvimento técnico. O importante é intensificar os mecanismos de diálogo entre a ciência e suas aplicações, ao invés de se ficar discutindo os direitos da ciência de investigar ou não determinados temas.

\section{Orlando Ferreira Junior}

Discordo do dr. Win quando diz que problema sério é a clonagem colocar uma réplica genômica no mundo. Na verdade a natureza já faz isso. Os gêmeos univitelinos são um exemplo que nunca lesou ninguém.

Antes de abordar a metodologia que pode vir a ser utilizada para clonagem humana - a transferência nuclear -, eu gostaria de falar sobre terapia gênica, uma manipulação genética de células somáticas, que vem sendo discutida há muitos anos. Enquanto a clonagem humana é uma perspectiva para o futuro, a terapia gênica já é uma realidade. Por meio dela corrigimos alguns defeitos genéticos a partir de células somáticas de um indivíduo. 
Tomo como exemplo a deficiência da enzima adenosina deaminase, que faz com que os linfócitos T não sejam funcionais. O linfócito $\mathrm{T}$, como todos sabem, é uma célula originária da medula óssea, e a medula óssea é responsável pela produção das células chamadas hematopoéticas ou células progenitoras hematopoéticas. É possível então, através da terapia gênica, retirar estas células do bebê e tratá-las in vitro, trocando o gene defeituoso. As células são devolvidas à criança, e, à medida que a medula óssea amadurece, produz células que estão agora 'curadas'. Essa é a idéia básica da terapia gênica ou transferência gênica, de células somáticas. Evidentemente, como todo procedimento, tem seus riscos, no caso, risco individual e não populacional.

Ela suscitou também questões éticas e sociais que tiveram de ser resolvidas ao longo do tempo. Como exemplo, cito as resoluções do Parlamento alemão, de 1984 e 1986, e de outros comitês internacionais que estudavam o assunto. Declaravam que ela era uma extensão bem-vinda de uma gama de opções terapêuticas disponíveis ao homem. Naquele momento, a terapia gênica era apenas um sonho, mas já era discutida sob o ponto de vista ético e científico. Este é um ponto importante. A sociedade ficou preparada para esta tecnologia, não foi pega de surpresa pelas opções que ela trouxe. Portanto, em condições favoráveis, a reflexão ética deve preceder o progresso tecnológico e nos preparar para suas conseqüências.

No debate, os potenciais riscos são confrontados com os potenciais benefícios, visto que a aceitação de uma forma de tratamento médico não implica o desaparecimento de riscos. Simplesmente, eles são relegados a outro plano. Dou como exemplo o transplante cardíaco, que sempre pressupôs um risco de vida muito grande, por uma série de razões cirúrgicas, imunológicas etc. Hoje ninguém mais fala nisso. É o que chamo de 'banalização' da tecnologia.

Com relação à terapia gênica de células somáticas, existem algumas questões ainda pendentes e que vão nos levar diretamente à transferência nuclear. A primeira é que não há limite claro - como disso o dr. Win entre o que é terapêutica ou prevenção e o que é melhoramento. Até onde você está tratando uma doença ou melhorando o ser humano, isso não foi resolvido ainda. Outra questão importante: apesar de seu leque de aplicações, a terapia gênica é a manipulação de células germinativas, e que é exatamente o cerne da questão da transferência nuclear.

Uma conclusão me parece clara: é a impossibilidade de garantir máxima liberdade de pesquisa a pretexto de progresso terapêutico, e, ao mesmo tempo, assegurar que a pesquisa seja bem conduzida, não tenha aplicação que vá além de sua razão terapêutica inicial.

Dito isso, gostaria de passar à transferência nuclear, começando pelo que pretendia o trabalho publicado na revista Nature, em 27 de fevereiro, com aquele título, por aqueles autores. Não tinha nada a ver com clonagem humana. O objetivo era muito claro: verificar se a transferência de um núcleo único proveniente de um estágio específico de diferenciação celular para um ovócito nuclear não fertilizado possibilitaria investigar se esse estágio determinado de diferenciação celular ficaria comprometido por mutações genéticas irreversiveis. Objetivo complicado e simples ao mesmo tempo. $\mathrm{Na}$ verdade, era pesquisar o que dr. Win comentou - se uma célula diferenciada poderia reverter e se tornar célula multipotente. 
E a conclusão dos autores tampouco tem a ver com clonagem humana: a diferenciação celular não está envolvida em modificações irreversíveis do material genético, requeridas para o desenvolvimento de um animal a termo. A única conclusão que abre caminho para clonar um ser humano é a de que, tornando a célula doadora aquiescente, será possivel obter o desenvolvimento normal de uma variedade de células - e eu acrescentaria aqui - de espécies diferenciadas. Do ponto de vista científico, muito pouco se contribuiu para a clonagem humana. Amanhã, qualquer laboratório que tentasse clonar um ser humano teria de esperar pelo menos nove meses para ele aparecer, talvez até um pouquinho mais.

O mais importante são as limitações que o mencionado trabalho apontou. Em primeiro lugar, não há nenhuma informação sobre a longevidade ou a fecundidade dos animais clonados. Segunda limitação: a técnica de transferência nuclear é específica para cada par de célula doadora e receptora. É preciso padronizar o estágio do ciclo celular da célula doadora do núcleo com a célula receptora desse núcleo. Isto fica claro quando se analisam outros modelos animais, como o sapo mencionado por mim e, também, o camundongo. Essa sincronia do estágio do ciclo celular entre a célula doadora e a receptora é tremendamente importante, e eu não tenho conhecimento de que exista algum estudo desse tipo com célula humana. Um terceiro ponto muito importante é a eficiência do método. Com base na tabela aqui apresentada, vemos que, por esta metodologia, o índice de animais nascidos, seja por transferência de núcleo de adulto, de feto ou de embrião, fica sempre em torno de $1 \%$. Jamais chega a $10 \%$, o que é muito inferior aos índices da inseminação artificial ou ao método natural de obtenção de filhos.

\begin{tabular}{|lccc|}
\hline & \multicolumn{3}{c|}{ Origem do núcleo } \\
\hline & Adulto & Feto & Embrião \\
\hline Núcleos transferidos & 277 & 172 & 395 \\
Embriões obtidos & $11 \%$ & $20 \%$ & $23 \%$ \\
Animais nascidos & $0,4 \%$ & $1,2 \%$ & $1,3 \%$ \\
\hline
\end{tabular}

Nesse ponto, pergunto: quais são as perspectivas inauguradas pela clonagem gênica por transferência nuclear? Primeiro, conhecimento científico. Este trabalho abriu uma série de linhas de pesquisa, como, por exemplo, o encurtamento telomérico. O telômero é uma sequência de DNA que fica no final do cromossomo. Algumas células in vitro envelhecem, isso está associado à perda dessas seqüências do cromossomo. Agora tem-se um modelo para estudar o ‘envelhecimento' celular. Também concerne à relação de núcleocitoplasma a que aludiu o dr. Win, isto é, há algum fator de transcrição que faz com que o par doador-receptor leve a termo essa célula, esse ovo. Existe, também, a possibilidade de se elucidar o mecanismo de controle da diferenciação celular. Muito importantes seriam os estudos das doenças mitocondriais, como a miopatia e a encefalopatia. Isto porque, se chamarmos 


"Refletindo sobre
a frase de um
editorial da
revista Nature
sobre a clonagem
da ovelha,
pergunto: será
que o homem
tem o direito de
brincar de Deus?"

"Refletindo sobre a frase de um editorial da revista Nature sobre a clonagem da ovelha, pergunto: será que o homem brincar de Deus?" o oócito de mãe, a única coisa que o clone vai ter da mãe são as mitocôndrias. As doenças que afetam esses corpúsculos só são transmitidas pela mulher, porque o óvulo tem grande quantidade de citoplasma e, portanto, de mitocôndrias, e o espermatozóide tem pouca.

Com relação ao desenvolvimento tecnológico, talvez fossem admitidas, do ponto de vista ético, a clonagem de animal adulto de forma assexuada, e a clonagem de quimeras, lembrando oJurassic Park, onde se combinou um ovo de uma espécie com o núcleo de outra.

Outros usos vantajosos seriam a manutenção de raças não-humanas em extinção, e a produção de alimentos através de rebanhos selecionados, o que implicaria o desenvolvimento de bancos de genes ou de genomas que garantiriam a variabilidade genética no futuro, caso esses rebanhos fossem perdidos.

A clonagem de seres humanos para a perpetuação genética de certa forma já é praticada, com a inseminação artificial de indivíduos não férteis. $O$ indivíduo poderia ter um filho de outra maneira — por adoção ou inseminação com esperma de doador - , mas insiste em ter seu genoma herdado ou transmitido para a prole. Faço aqui um comentário: o indivíduo não é apenas um ser biológico. Sua descendência é determinada por valores culturais e emocionais. Portanto, no futuro, essa perpetuação pode se tornar uma bobagem sob o ponto de vista da clonagem gênica.

Existe, também, a possibilidade de se criarem reservas terapêuticas de células ou órgãos. Com elas a vida não seria mais um fim e sim um meio para se conseguir continuar vivendo.

Para concluir, lembro que teremos filhos biológicos sem necessidade de esperma humano, bastando o sexo feminino para a manutenção da espécie. Assim, pensando no comentário do dr. Paulo, eu diria que, se o clone vai ter um sexo no futuro, será o feminino.

Acho que é importante indagar qual a justificativa médica e científica para a clonagem humana. Existe realmente? Refletindo sobre a frase de um editorial da Nature sobre a clonagem da ovelha, pergunto: será que o homem tem o direito de brincar de Deus? Já que estamos falando em Deus, e o dr. Paulo perguntou se o clone vai ter alma ou espírito, eu diria que, para os agnósticos ou ateus, tanto faz. E aos crentes, pergunto: será que Deus permitiria a clonagem de um ser humano se não fosse por Sua livre e espontânea vontade?

\section{Marcos Segre}

Não tenho medo do clone. Tenho medo, sim, de não conseguir refletir sobre toda a problemática aventada pelos que me precederam, refletir livremente, esbarrando em emoções, para colocar alguma racionalidade em meio a essa turbulência provocada pela possibilidade da clonagem humana. Acho isso bastante difícil, mas apaixonante.

Logo depois da clonagem da ovelha Dolly, vi uma foto do pesquisador Ian Wilmut, na Casa Branca, onde se reuniu com parlamentares dos Estados Unidos. Não sei se foi minha fantasia, mas vi este homem com os olhos marejados de lágrimas, dizendo não, ovelha tudo bem, clone humano, nunca. Senti nas lágrimas que minha fantasia detectou uma enorme hipocrisia. Será que ele tem tanto medo assim do clone humano? Acho que não. Mas diante do pânico criado pela idéia de clonagem humana, ele tem medo que the cortem as verbas para as pesquisas. 
Vi pela imprensa Sua Santidade, o papa, o presidente Chirac, o presidente Clinton, todos contrários à clonagem humana, dizendo que vão estabelecer medidas para conter tudo isso. E logo vieram à tona as experiências feitas nos campos de concentração nazistas, o livro Admirável mundo novo, o filme Os meninos do Brasil, enfim, todo um conjunto de referências que não simbolizavam o medo, medo da novidade, medo de algo que nunca aconteceu, medo da ciência, esse medo que vem de longe e que se materializou, por exemplo, na Inquisição, quando se afirmou, pela primeira vez, que a Terra não era o centro do universo. Tanto que Galileu teve de mudar sua afirmação, pelo menos exteriormente.

Fiz outras anotações que vão ajudar nossa reflexão. Por exemplo, falouse no projeto Genoma e no risco que representa para a discriminação do ser humano. E minha mente, em outra associação livre de idéias, evocou uma notícia do Conselho Regional de Medicina de São Paulo, segundo a qual muitas empresas de lá exigem testes de gravidez para a admissão de funcionárias, pois não querem empregadas grávidas que farão jus à licença maternidade e a outros beneficios que nossas leis ainda conferem. Discriminam também o indivíduo HIV, embora se saiba que ele tem possibilidades de viver de maneira produtiva por muitos anos.

Associando mais idéias, vou para outros pensamentos. E os genocídios que acontecem? As cenas que vemos nos jornais do que se passa na África. Se pensarmos no que talvez aconteça no Oriente Médio, fruto do fanatismo de muitos. Se lembrarmos o que aconteceu nos campos de concentração nazistas. Foi trágico, e naquela época não havia engenharia genética, genoma, clonagem...

Estou querendo trazer para vocês uma visão da bioética, que é a parte da ética que cuida da vida, da saúde e da morte humana. Concebo a ética como algo pré-legal, pré-cultural e pré-moral. Algo que vem de cada sujeito, que é eticista, pensador, legislador de forma autônoma.

Kant dizia que todo homem dotado de razão tem condições de ser um legislador universal. Gostaria de acrescentar que todo homem dotado de razão e de sentimentos tem condições de estabelecer princípios éticos. Por que, então, quando surge alguma coisa nova, temos de recorrer a parâmetros morais ou legais anteriores, ou temos de ir para a religião ou outros pontos de apoio? Por que não nos sentimos em condições de dizer, por nós mesmos, se determinada prática será ética ou não? $O$ que é a ética senão uma hierarquização de valores? O que é mais importante, a vida humana ou a liberdade? A preservação da subjetividade humana, em todos os seus aspectos, ou a massificação, a globalização? Ética, então, é algo que estamos estruturando a todo momento, ao pensarmos sobre as situações emergentes.

Quando for feito o primeiro clone humano, e o bebezinho estiver sendo fotografado pela imprensa, gostaria de saber se vamos parar para pensar se ele tem alma, se é disponível para doar órgãos, se podemos matá-lo, ou se não tem qualquer significado. Porque é este tipo de contato que eu considero uma aproximação ética. O prof. Affonso lembrou que os conquistadores espanhóis e portugueses achavam que os índios não tinham alma. Lembro outro fato: os teólogos cristãos da Idade Média falavam que a alma só penetrava no feto masculino quarenta dias depois da coabitação; e no feto feminino, oitenta dias.

Desse modo, vejo que na história da humanidade, sempre que surgiram situações novas, os homens correram para as religiões ou para os juristas. E 
"O homem brinca de Deus? Não gosto do termo brinca, mas acho que o homem é Deus." precisaram mesmo disso. Não estamos propondo uma liberação geral em termos de genética. É evidente que a legislação e a ética precisam permanecer vigilantes. Entidades reguladoras são necessárias, como a Comissão Nacional de Ética em Pesquisa, que, no ano passado, normatizou a pesquisa em seres humanos.

Em 1985, fui entrevistado sobre uma questão que se dera no México. Uma moça pedira aos tribunais para ser engravidada com o sêmen do próprio pai, que era portador do Mal de Alzheimer. O feto seria produzido tãosomente para a retirada de massa encefálica para curar a doença do pai. Dei vários tipos de resposta. Em termos legais, aquela fecundação, mesmo in vitro, era absolutamente proibida. Em primeiro lugar, por ser incestuosa, o que é contra a moral vigente. Em segundo, não me constava, talvez por ignorância minha, que tal tipo de experimento tivesse lastro científico suficiente para que fosse tentado. Em terceiro, a idéia de se produzir um embrião com a finalidade específica de se retirar um órgão dele, ainda que para tratamento, chocava-me. Ia terminando minha entrevista, quando disse: essa é minha opinião hoje; posso mudar amanhã ou, quem sabe, a sociedade mude. Talvez daqui a algumas décadas existam laboratórios produzindo fecundação in vitro com a finalidade de tratar doenças. É uma questão de valores. Naquele momento, os meus foram feridos. Mas os valores são mutantes, a sociedade os altera. Eu mesmo posso rever posições com relação a muitas situações criadas pelo avanço tecnológico e científico.

Acho que não se pode pensar em ética com valores apriorísticos. Ela emerge da individualidade de quem quer pensar e sentir. Não existe uma regra que seja inerente a todos os seres humanos. Cada um tem sua maneira de sentir, de avaliar, o que é mais e o que é menos importante. Podemos organizar uma sociedade através do que Engel Kart, um bioeticista americano, denomina ética procedural. Através do entendimento, vamos ter que estabelecer um acordo definindo o que a maior parte da sociedade aceita. Isso ficará valendo como lei. Mas nunca vamos poder antepor a lei ao fato. A lei é toda ela baseada em fatos que aconteceram. As religiões são todas elas erigidas à luz de determinados momentos. Sempre lembro de Moisés e de seu Decálogo, proclamando "Não matarás". Esse mandamento era pragmático. O povo que ele conduzia à terra prometida estava acabando porque se matavam uns aos outros. Se perguntassem a Moisés: posso matar o beduíno que vem do deserto?, provavelmente ele diria: "você ganha medalha, porque preserva a integridade do seu povo". Então, primeiro temos a ética emergindo de cada um, depois a moral consolidada, e, por fim, a lei.

Para concluir, respondo ao prof. Orlando, que perguntava se o homem pode brincar de Deus. Eu acho que o homem vem sendo parceiro de Deus há muito tempo - quando alonga a vida humana, tratando de determinadas doenças; quando faz engenharia genética; quando modifica seu habitat; e, agora, com a capacidade de mudar a si mesmo. O homem brinca de Deus? Não gosto do termo brinca, mas acho que o homem é Deus. Com sua capacidade criadora, com sua capacidade de avaliar o certo e o errado, e, diante de novos avanços científicos, de dizer: isto é bom, isto é ruim, isto vai ser destrutivo para a espécie humana, isto vai acabar com a biodiversidade, isto vai permitir a subjugação. Enfim, este é o homem-Deus que eu gosto de pensar e de sentir. Não gosto do homem vassalo que diz: isto eu não faço porque é contra a lei natural. Assim não evoluímos. 
Para dar um arremate final em minha concepção de ética, lembro uma reunião a que assisti na Sociedade de Medicina Legal e Criminologia de São Paulo. Um grupo de professores passou três a quatro horas discutindo o uso do dispositivo intra-uterino (DIU). Queriam saber se era uma prática abortiva ou anticoncepcional. Saí da reunião me perguntando que importância isso tinha naquele momento. E agora a clonagem trouxe um argumento fantástico: já se pode fazer um ser humano sem fecundação. Será que, por não ter havido fecundação, o clone não será considerado um ser humano? Não terá sua dignidade? Não terá seus direitos respeitados? Claro que não! Pelo menos no que depender de mim.

\section{Senadora Marina Silva}

Confesso que foi gratificante ouvir os ilustres expositores. Para quem nâo tem formação na área, mas, como eu, tem a obrigação de fazer leis, participar de discussões como essa é um aprendizado importante, já que, ao elaborarmos leis, procuramos traduzir os consensos éticos, morais e culturais da sociedade.

Quando aparecem problemas novos, como este, ou perante outros que a humanidade já vivenciou, precisamos ter cuidado com o maniqueísmo das posições. Os que são favoráveis elencam todos os argumentos para justificar seu sim; os contrários reúnem argumentos para dizer não.

Acho que o posicionamento ético do indivíduo só se forma na diversidade, que é, a um só tempo, biológica, cultural e social. Assim, é importante que a religião e a moral se manifestem. Elas são parte do nosso consenso ético. É que os indivíduos se manifestem. Mas a coletividade, talvez o inconsciente coletivo da humanidade à qual todo grupo social pertence, também se manifesta, $\mathrm{e}$ é então que nos enternecemos com o bebezinho no berço ou simplesmente o tratamos como se pudesse crescer e virar escravo. Nossa ética, na Antiguidade, já permitiu que encarássemos pessoas como não sendo gente - os escravos gregos, por exemplo. Até recentemente, em nossa civilização, os escravos não eram considerados humanos, e isto era consenso ético.

Será que a ética, hoje, já não começou a mudar, também, em relação aos seres humanos de primeira e de segunda classe? Os filhos da classe média são crianças, os dos pobres são pivetes ou moleques. Nós nos enternecemos quando um filho nosso é assaltado e morto por causa de um tênis. Contudo, todos os dias morrem crianças de outras classes, e não nos revoltamos tanto. Nossa ética permite dois níveis de avaliação. Muitas vezes o propósito puro e limpo dos indivíduos se altera no âmbito do coletivo, onde prevalece a ética social, moral, com todas as suas contradições.

Gostei muito quando o prof. Marcos Segre disse que o homem não é vassalo de Deus, e sim Seu parceiro, tendo, por isso, que aprender a arbitrar com justiça. Este é o grande desafio ético da humanidade. O conceito de justiça pressupõe uma avalição ética, e como ela se forma nos indivíduos, temos que recorrer à cultura para que a nossa ética não privilegie apenas o nosso ponto de vista.

\section{Leila Oda}

Tendo em vista que a clonagem propicia a diminuição da biodiversidade, gostaria que a mesa comentasse a possível eliminação de espécies e o surgimento de pragas, por conta da alteração de ecossistemas, que poderiam dizimar espécies inteiras. 
Outra questão que gostaria de apresentar à mesa é a clonagem setorial como perspectiva de desenvolvimento científico em prol do homem. Assim, já que o transplante de órgãos é hoje um problema sério, em razão da carência desses órgãos, quais seriam as perspectivas - que se coloquem prós e contras - da utilização da clonagem setorial, e como poderia ser equacionada do ponto de vista jurídico?

\section{Win Degrave}

Em relação à primeira questão, digo que a biodiversidade seria diminuída, sim, só que isso já acontece com os procedimentos atuais. A seleção genética e fenotípica de plantas e animais para fins de produção está sendo feita, e a diversidade genética dessas criações é realmente muito baixa. Acho que a clonagem de animais e plantas será usada em grande escala para a produção, e que isso não acarretaria um problema maior do que o que já temos. Contudo, com o surgimento de algum vírus ou alguma doença nova, a população inteira de um animal ou planta clonados poderia ser dizimada. Penso que deve ser enfatizada a preservação do genótipo das diferentes espécies isoladas no mundo, como se faz com plantas na Embrapa. É necessário preservar a biodiversidade por este lado, conquanto a clonagem não teria tanta interferência nesse processo.

À medida que se vai cultivando mais, ou ocupando mais a terra, vai-se destruindo a biodiversidade natural. Aqui, sim, ocorre diminuição drástica da diversidade. No processo de clonagem, vamos simplesmente substituir o que já foi uniformizado por melhoramento genético pela uniformização por clonagem

Por isso, acho que não haverá grande problema. Ao contrário, pois, concomitantemente à clonagem, deverão existir técnicas de mudança genética ou engenharia genética com clones que poderão até propiciar um conhecimento maior da diversidade genética das espécies.

\section{Fermin Roland}

Frisou-se nessa discussão que o problema substantivo hoje, numa visão antropocêntrica, é a clonagem de seres humanos. O que afinal vai ser clonado? A biologia será clonada, mas não se vão clonar as circunstâncias. Elas vão ficar de fora, assim como a ocupação do mesmo espaço-tempo, os sentimentos, as experiências e todas as características que constituem a personalidade. Nesse caso, se é a mera biologia que se vai clonar, como será, por exemplo, fazer vários Michael Jordan? Eles podem ter o físico, e não querer nada com a bola. Agora vem minha questão, que está ligada à biodiversidade. O ser humano é um ser biológico, sim, mas também é cultural, técnico, científico. Ele cria o quê? Cria diferença cultural, e esta pode ser uma aliada da biodiversidade. Pode-se supor isto. O que me leva à seguinte questão ética: se amanhã nascer um filho nosso resistente às doenças emergentes, justifica-se ou não a clonagem desse novo ser? Acho que sim, pelo menos do ponto de vista sanitário é válido preservar essa diversidade dada pela clonagem. E, mais além, pode-se até supor que isto não seja um produto da própria evolução, mas que seja pensado em laboratório.

\section{Fernanda Carneiro}

Trabalho com questões da ética e com o tema da reprodução humana. Sinto-me desafiada pelo poder técnico-científico. Acho que precisamos discutir 
“ O ser humano é um ser biológico, sim, mas também é cultural, técnico, científico. Ele cria o quê? Cria diferança cultural, e esta pode ser uma aliada da biodiversidade." por que uma pesquisa deve ser feita, para que deve ser feita, e, no caso da clonagem, com que finalidades. Entretanto, gostaria de discutir alguns pontos abordados aqui. Mesmo que sejamos mutantes em termos de valores, há valores que precisam ser mantidos de forma mais permanente possivel. A dignidade humana é um deles. Não creio que devamos estar vulneráveis à mudança de valores a ponto de permitir uma sociedade onde a dignidade humana seja - como já está sendo - depreciada.

Então, há momentos em que os valores são apriorísticos, sim. Em sua intervenção, o dr. Segre, incorre até numa contradição quando diz que a maioria da sociedade vai dizer qual o rumo correto a tomar. Há um valor apriorístico aí: o de que a maioria tem razão. Penso que trabalhamos com valores a priori, que vêm dos ethos, daí eu discordar da existência ética individual.

Creio que os ethos são algo que acontece no mundo dos costumes e hábitos, e são contraditórios. Convivo com diversos ethos: cristão, afrobrasileiro, um mais ligado a populações tradicionais, o etbos científico etc. Este tem hoje um interativo de comportamento no meio da assistência médica - que a ciência prevalece em detrimento de outros ethos, e a ética seria, digamos, a tentativa de regular este conflito de valores em que todos estamos imersos. Para mim, existe uma moral que me guia e um sistema de valores ao qual me apego para decidir o que é de minha responsabilidade pessoal.

A clonagem suscita toda uma discussão sobre vantagens e desvantagens, benefícios imediatos a longo prazo, individuais ou coletivos, mas há o temor provocado pela clonagem de um ser humano. A diferença entre o sempre citado exemplo dos gêmeos univitelinos e um clone é imensa. Os gêmeos são contemporâneos, os clones nascem em tempos diferenciados. Atenta ao valor justiça, vejo que o clone nasce em condições desiguais. Já nasce com um padrão, um mapa conhecido, sem o direito de ser ignorante a respeito de si mesmo, e de possuir uma subjetividade singular. Então creio que a questão é mais de fundo existencial que de risco biológico.

O que mais me comove é o argumento existencial do que significará ser clone para o próprio clone. Acredito que, pelo bem dele, seria bom que não nascesse com essa desigualdade. Se já é possível clonar uma pessoa, por prudência e respeito a esse futuro ser, é melhor que a gente não o faça.

\section{Cristina Possas}

A questão fundamental é a perplexidade diante do novo, diante daquilo que parece incontrolável. Como a sociedade lida com o novo? Como avaliar os fatores que estão orientando as nossas decisões? Devemos aprofundar esse debate para não corrermos o risco dę ter de enfrentar uma situação sem estarmos preparados para lidar com ela, do ponto de vista ético.

Não vejo esta questão da clonagem de forma tão negativa. Penso que estamos contaminados pela ficção científica, que muitas vezes coloca o clone como escravo, desprovido de vontade, ou como ser totalmente modificado que, de repente, toma conta do mundo. Temos que olhar também o lado positivo desse processo de conquista, a possibilidade de se obter avanços consideráveis a partir da clonagem.

\section{Orlando Ferreira Júnior}

O dr. Roland mencionou um caso significativo, a clonagem de indivíduo resistente às doenças emergentes. A natureza já faz isso. E ilustro com um 
tema bem recente: descobriu-se que existem indivíduos resistentes ao HIV. A biodiversidade foi diminuída pelo vírus, naturalmente. Não foi preciso clonar. Os indivíduos que morreram tiveram sua diversidade excluída da face da terra por um vírus. Então, sob esse aspecto, acho que a clonagem não diminui a biodiversidade porque a natureza já faz isto.

\section{Marcos Segre}

Gostei muito do questionamento da dra. Fernanda Cameiro. Realmente, é uma questão existencial. Estou acostumado a sentir pessoas que pensam existencialmente de forma oposta à minha. $\mathrm{E}$ como são coisas da alma, às vezes são difíceis de expor. Quando você fala na dignidade, como valor que deve ser preservado, coloca-o como obrigação e, assim, como algo que vem de fora. Não concebo a ética dessa maneira. Tanto se escreveu sobre respeito à dignidade, e o que estamos vendo? Deveres não são cumpridos. Então, em termos existenciais, prefiro minha maneira de sentir a ética, de dentro para fora. Não sei dizer se os valores atuais serão preservados, apenas sei dos meus valores neste momento. De que maneira posso trabalhar para que sejam mantidos? Acho que fazendo o que estamos fazendo, discutindo, passando reflexões e ensinamentos.

Não adianta querermos uma regra que eternize valores. Não sei qual é a tendência do Brasil com relação à aceitação da clonagem. Posso dizer, com a minha individualidade, que acho uma coisa boa, desde que, como todo progresso científico, seja continuamente analisado, e reestudado. Acho que é cada um de nós que vai escolher os caminhos para que haja ou não fracasso. Então, se nos olharmos por dentro, temos uma possibilidade de avaliação maior do que simplesmente observando de fora o fenômeno histórico.

\section{Keyla Marzochi}

Gostaria de perguntar: como multiplicar os parceiros em detrimento dos vassalos? Como fazemos isto numa instituição de pesquisa? Como ampliar a massa crítica na questão da consciência e da responsabilidade? Há formas de se trabalhar isso institucionalmente? Enfim, acho que pelo menos em ilhas de reflexão, como a Fundação Oswaldo Cruz, podíamos tentar trabalhar as questões éticas paralelamente ao crescimento técnico-científico.

\section{Marli Albuquerque}

Gostaria de dizer que tanto no campo ético, quanto no científico, não estamos navegando sobre verdades puras. A ciência, com todas as suas implicações e relações com a sociedade, seus benefícios e riscos, possui uma história. O homem é um ser cultural, histórico, biológico, racional e construiu uma racionalidade utilitarista a partir de Descartes, que é o mundo da razão, o mundo que estabelece verdades que o homem domina. $E$ isto me traz o alerta de Joshua Lederberg, considerado um dos grandes geneticistas do mundo. Ele colocou a seguinte questão: mesmo que o recorte ético seja artificial, é necessário que esteja na dianteira dos processos científicos, porque a ciência, sobretudo a biotecnologia, no final do século $\mathrm{XX}$, deixou de ser apenas investigação das questões da vida para se tornar um poderoso negócio. Então, temos que admitir a escolha dos recortes que julgarmos necessário fazer. O recorte ético é construído, tanto quanto os projetos no campo da ciência e da biotecnologia. 
"E o clone o que é? É outro, se for criado.

Trabalhamos sempre no terreno da fantasia, pois nem sei se vai existir um clone. Mas a pergunta é: por que ter medo?"

\section{Marcos Segre}

Curioso, quando se discutem temas como clonagem ou engenharia genética, ouvimos muitas pessoas falarem em determinismo genético. Quem pode negar o poder fantástico do DNA? Também ouvimos falar das experiências de vida, da cultura e de todas as influências que se exercem sobre o ser em mudança. E aí está minha surpresa. Aqueles que colocam essas situações falam de nós como seres absolutamente determinados: o que é genético, o que é social, o que é cultural, o que é afetivo etc. Então pergunto: o que eu estou fazendo nesse contexto como individualidade? Penso que aqui há um paradoxo interessante. Não vou dizer que acredito em alma, mas acho que convivemos com um mistério, que é nossa própria existência. A convivência com este mistério é tão difícil, que vamos buscar explicações na religião, na ciência, no DNA. Na verdade não conseguimos explicar nada. Quis trazer essa divergência, porque se me perguntarem se o clone tem alma, acho que, se eu tenho, ele também tem. A alma não é definível, é algo como essência, como capacidade de ser, de sentir e de priorizar valores também, como Deus. Alma é a individualidade do sujeito. E o clone o que é? É outro, se for criado. Trabalhamos sempre no terreno da fantasia, pois nem sei se vai existir um clone. Mas a pergunta é: por que ter medo? Por que recorrer a parâmetros que não vamos achar? Não podemos ter parâmetros com relação a situações que são novas. Então temos que ter prudência, vigilância, atenção. Mais do que isso, além de não ser humano, não é possível.

\section{Ficha técnica}

Transcrição das fitas:

Maria Luiza Tulchinski, Sheila Sotelino da Rocha

Conferência de fidelidade:

Anna Beatriz Almeida,

Rosária de Mello Dias, Tânia do Nascimento

Edição:

Jaime L. Benchimol, Ruth B. Martins

Revisão:

Rosa Maria Mello Dias

Digitalização e tratamento de imagens:

Fernando Vasconcelos 


\section{REFERÊNCIAS BIBLIOGRÁFICAS E LEITURAS COMPLEMENTARES}

Amaral, M. T. (org.) 1996

Atlan, H. e Bousquet, C. 1994

Atlan, $\mathrm{H}$. 1991

Atlan, $\mathrm{H}$. 1986

Ballard, J. G. 1992

Ballard, J. G. 1988

Barros, M. de 1996

Castiel, L. D. $1996 a$

Castiel, L. D. $1996 \mathrm{~b}$

Castoriadis, C. 1987

Cohen, J. $1997 a$

Cohen, J. $1997 \mathrm{~b}$

Colwell, R. R. 1996

Edelman, G. M. 1992

Ferreira, A. B. de H. 1975

Kahn, A. 16.3.1997

Kennen, R. H. 1996

Krieger, N. e Zierler, S. 1996

Krieger, $N$. 1994

Lewontin, R. C. 1992
'O vigor da cultura comunicacional: o paradoxo moderno contemporâneo'. Em Contemporaneidade e novas tecnologias. Rio de Janeiro, Sette Letras.

Questions de vie: entre le savoir et l'opinion. Paris, Seuil.

Tout, non, peut-être: éducation et verité. Paris, Seuil.

A tort et à raison: intercritique de la science et du mythe. Paris, Seuil.

'Project for a glossary of the $20^{\text {th }}$ century'. Em J. Crary e S. Kwinter (orgs.), Incorporations. Nova York, Zone Inc., pp. 268-79.

Crash!

São Paulo, Marco Zero.

Livro sobre nada.

Rio de Janeiro, Record.

Moléculas, moléstias, metáforas: o senso dos bumores. São Paulo, Unimarco.

'Vivendo entre exposições e agravos: a teoria da relatividade do risco'. História, Ciências, Saùde - Manguinhos, vol. III(2): 237-64.

As encruzilhadas do labirinto 1. São Paulo, Paz e Terra.

'The genomics gamble'. Science, vol. 275, pp. 767-76.

'Exploiting the HIV-Chemokine nexus'. Science, vol. 275, pp. 1.261-4.

'Global climate and infectious disease: the cholera paradigm'. Science, vol. 274, pp. 2.025-31.

Bright air, briliant fire: on the matter of the mind. Nova York, Basic Books.

Novo Dicionário da Lingua Portuguesa. Rio de Janeiro, Nova Fronteira.

'Depois de Dolly'. Folba de S. Paulo, Caderno 5:4.

'The at-risk health status and technology: a diagnostic invitation and the gift of knowing'. Social Science and Medicine, vol. 42, 11: 1.545-53.

'What explains the public's health? A call for epidemiologic theory'. Epidemiology, vol. 7, 1:107-9.

'Epidemiology and the web of causation: has anyone seen the spider?' Social Science and Medicine, vol. 39, 7:887-903.

Biology as ideology: the doctrine of DNA.

Nova York, Harper Collins Publ. 
Lolas, F. 2-6 jun. 1997

Love, $\mathbf{R}$. 1996

Lyotard, J. F. 1996

Machado, J. P. 1956

Macintyre, $\mathrm{S}$. 1995

Marigny, J. 1996

Matthews, R. 1997

Mc Dade, J. E. e

Anderson, B. E. 1996

Mac Michael, A. J. 1995

Mendes-Gonçalves, R. B. 1992

Moreno, R. e

Rothhammer, F. 1994

Nelkin, D. e Lindee, M. S. 1995

Pennisi, E. e Williams, N. 1997

Provine, $W$. 1991

Rabinow, P. 1992

Richards, M. P. M. 1996

Richards, M. P. M. 1993

Rose, $\mathrm{S}$. 1997

Samaja, J. 1997

Santos, B. S. 1995
'Derechos humanos y salud: consideraciones bioéticas'.

Texto apresentado no IV Congresso Latinoamericano de Ciencias Sociales y Salud, México. (mimeo.)

'Knowing our genes'.

Public Understanding of Science, 5: 21-7.

Moralidades pós-modernas.

Campinas, Papirus.

'Verbete bibrido'. Em Dicionário Etimológico da Língua Brasileira. Lisboa, Confluência, p. 1.172.

'The public understanding of science or the scientific understanding of the public? A review of the scientific context of the new genetics.

Public Understanding of Science, 4: 223-32.

'Relações entre a ciência e o irracional na literatura fantástica e na ficção científica anglo-saxônica'. Em $A$ ciência e o imaginário. Brasília, EdunB, pp. 53-78.

'How right can you be?'.

New Scientist, Editorial, vol. 153, 2.072: $25-31$.

'Molecular epidemiolgy: applications of nucleic acid amplification and sequence analysis'. Epidemiologic Reviews, vol. 18, 1: 90-7.

Ia epidemiología molecuar: ¿nueva ruta de investigación o compañero de viaje?'. Boletín de la Oficina Sanitaria Panamericana, 119(3): 243-54.

'Contribuição à discussão sobre as relações entre teoria, objeto e método em epidemiologia'. Anais do I Congresso de Epidemiologia - 1990. Rio de Janeiro, Abrasco, pp. 346-61.

'Debate sobre o artigo de Castiel'.

Cadernos de Saúde Pública, vol. 10, 3: 309-10.

The DNA mystique: the gene as cultural icon.

Nova York, Freeman.

'Will Dolly send in the clones?'. Science, 275: 1.415-6.

'Hereditariedade'. Em Enciclopédia Einaudi Organismo - Hereditariedade. Vol. 19, Lisboa, Imprensa Nacional/Casa da Moeda, pp. 212-58.

'Artificiality and enlightment: from sociobiology to biossociality'. Em J. Crary e S. Kwinter (orgs.), Incorporations. Nova York, Zone Inc., pp. 234-52.

'Lay and professional knowledge of genetics and inheritance'. Public Understanding of Science, 5: 217-30.

'The new genetics: some issues for social scientists'. Sociology of Health and Illness, vol. 15, 5: 567-86.

'A perturbadora ascensão do determinismo neurogenético'. Ciência Hoje, vol. 21, 126: 18-32.

Fundamentos epistemológicos de las ciencias de la salud. Tese de doutoramento, Escola Nacional de Saúde Pública/Fiocruz.

Pela mão de Alice: o social e o político na pós-modernidade. São Paulo, Cortez. 
Santos, L. G.

16.3 .1997

Schramm, F. R. 1996

Schramm, F. R. 1977

Schulte, P. A. e

Pereira, F. P. (orgs.) 1993

Sedgwick, E. K. 1992

Shy, O. M.

1997

Susser, M. e Susser, E. 1996

Susser, M. e Susser, E. 1966

Sfez, L.

1996

Thom, R.

1985

Tsouyopoulos, $\mathrm{N}$. 1994

Varela, F. J. 1992

Vaz, P. G. 1997

Vineis, P. e Porta, M. 1996

Wisnik, J.M. 6.5.1997

Zusman, Waldemar 6.3.1997
'Além da ética e da repugnância'.

Folba de S. Paulo, Caderno 5: 6.

'Paradigma biotecnocientífico e paradigma bioético'. Em L. M. Oda (org.), Biosafety of transgenic organisms in buman bealth products.

Rio de Janeiro, Fiocruz, pp. 109-27.

'O caso Dolly: relevância biotecnocientífica e moralidade da clonagem'. (mimeo.)

Molecular epidemiology: principles and practices.

San Diego, Academic Press.

'Epidemics of the will'. Em J. Crary e S. Kwinter (orgs.), Incorporations. Nova York, Zone Inc., pp. 582-95.

'The failure of academic epidemiology: witness for the prosecution'. American Journal of Epidemiology, vol. 145, 6: 479-84.

'Choosing a future for epidemiology I: eras and paradigms'. American Journal of Public Health, 86: 668-3.

'Choosing a future for epidemiology' II: from black box to chinese boxes and eco-epidemiology'. American Journal of Public Health, 86: 674-7.

A saúde perfeita: critica de uma nova utopia. São Paulo, Unimarco/Loyola.

Parábolas e catástrofes. Lisboa, Dom Quixote.

'Postmodernist theory and the physician-patient relationship'.

Theoretical Medicine, vol. 15, pp. 267-75.

Sobre a competência ética.

Lisboa, Edições 70.

O inconsciente artificial.

São Paulo, Unimarco.

'Causal thinking, biomarkers, and mechanisms of carcinogenesis'. Joumal of Clinical Epidemiology, vol. 49, 9: 951-6.

'Comunicação oral'. Em Aspectos simbólicos da bioética.

Palestra proferida na Escola Nacional de Saúde Pública, Rio de Janeiro.

'Clonificação: fatos e mitos'. O Globo. 